NBER WORKING PAPER SERIES

\title{
HOW DOES HOUSEHOLD SPENDING RESPOND TO AN EPIDEMIC? CONSUMPTION DURING THE 2020 COVID-19 PANDEMIC
}

\author{
Scott R. Baker \\ R.A. Farrokhnia \\ Steffen Meyer \\ Michaela Pagel \\ Constantine Yannelis \\ Working Paper 26949 \\ http://www.nber.org/papers/w26949 \\ NATIONAL BUREAU OF ECONOMIC RESEARCH \\ 1050 Massachusetts Avenue \\ Cambridge, MA 02138 \\ April 2020
}

The authors wish to thank Sylvain Catherine, Caroline Hoxby, Ralph Koijen, Amir Sufi, Pietro Veronesi, Rob Vishny and Neil Ning Yu for helpful discussions and comments. Constantine Yannelis is grateful to the Fama Miller Center for generous financial support. R.A. Farrokhnia is grateful to Advanced Projects and Applied Research in Fintech at Columbia Business School for support. We are grateful to Suwen Ge, Sypros Kypraios, Sharada Sridhar, George Voulgaris and Jun Xu for excellent research assistance. This draft is preliminary and comments are welcome. The views expressed herein are those of the authors and do not necessarily reflect the views of the National Bureau of Economic Research.

NBER working papers are circulated for discussion and comment purposes. They have not been peerreviewed or been subject to the review by the NBER Board of Directors that accompanies official NBER publications.

(C) 2020 by Scott R. Baker, R.A. Farrokhnia, Steffen Meyer, Michaela Pagel, and Constantine Yannelis. All rights reserved. Short sections of text, not to exceed two paragraphs, may be quoted without explicit permission provided that full credit, including $\odot$ notice, is given to the source. 
How Does Household Spending Respond to an Epidemic? Consumption During the 2020

COVID-19 Pandemic

Scott R. Baker, R.A. Farrokhnia, Steffen Meyer, Michaela Pagel, and Constantine Yannelis

NBER Working Paper No. 26949

April 2020

JEL No. D14,E21,G51

\begin{abstract}
We explore how household consumption responds to epidemics, utilizing transaction-level household financial data to investigate the impact of the COVID-19 virus. As the number of cases grew, households began to radically alter their typical spending across a number of major categories. Initially spending increased sharply, particularly in retail, credit card spending and food items. This was followed by a sharp decrease in overall spending. Households responded most strongly in states with shelter-in-place orders in place by March 29th. We explore heterogeneity across partisan affiliation, demographics and income. Greater levels of social distancing are associated with drops in spending, particularly in restaurants and retail.
\end{abstract}

Scott R. Baker

Kellogg School of Management

Northwestern University

2211 Campus Drive

Evanston, IL 60208

and NBER

s-baker@kellogg.northwestern.edu

R.A. Farrokhnia

Columbia Graduate School of Business

3022 Broadway

New York, NY 10027

farrokhnia@gsb.columbia.edu

Steffen Meyer

University of Southern Denmark

Campusvej 55

5230 Odense M

Denmark

stme@sam.sdu.dk
Michaela Pagel

Columbia Business School

3022 Broadway

Uris Hall

New York, NY 10027

and NBER

mpagel@columbia.edu

Constantine Yannelis

Booth School of Business

University of Chicago

5807 S. Woodlawn Avenue

Chicago, IL 60637

and NBER

constantine.yannelis@chicagobooth.edu 


\section{Introduction}

Disease epidemics have plagued human societies since at least the earliest days of recorded history. This paper presents the first study of how households' consumption and debt respond to an outbreak using transaction-level household data. As COVID-19 began to spread across the United States in March 2020, households across the country were faced with drastic changes in many aspects of their lives. Large numbers of businesses were closed by government decree and in many cities and states, Americans were required to limit trips outside and exposure to others following shelter-in-place orders.

While Americans adjusted how they lived and worked in response to uncertainty about how the future would play out, they also rapidly altered how and where they spent their money. This paper works to deploy transaction-level household financial data to provide a better and more comprehensive understanding of how households shifted spending as news about the virus spread and the impact in a given geographic area became more severe and far-reaching.

The extent to which both individual households as well as the economy at large have been upended is without recent precedent. Entire industries and cities were largely shut down, with estimates of the decline in economic activity hitting all-time records. Policymakers at all levels of government and across a wide range of institutions have worked to mitigate the economic harm on households and small businesses. However, the speed at which the economic dislocation is occurring has made it difficult for policymakers to properly target fiscal stimuli to households and credit provision to businesses. After all, little is known about how households respond in their spending to a pandemic on a scientific basis and across a larger number of households and geographies.

This paper aims to close this gap by utilizing transaction-level household financial data to analyze the impact of the COVID-19 outbreak on the spending behavior of tens of thousands of Americans. We use transaction-level data from linked bank-accounts from a non-profit that works with individuals to sustain savings habits. Transaction-level financial data of this type is a useful tool for understanding household financial behavior in great detail. In the context of the current COVID-19 outbreak, it can allow for a high speed, dynamic and timely diagnosis of how households have adjusted their spending, when they began to respond, and what the characteristics 
are of the households who have responded the fastest and strongest. ${ }^{1}$

News media reported that customers emptied supermarket shelves in an effort to stock-pile durable goods. ${ }^{2}$ Furthermore, as advice flowed from federal and state governments to households, one common refrain was that households should prepare to mostly stay inside their homes for multiple weeks with minimal trips outside. Home production is thus a source of savings that households can engage in which should also increase their spending at certain stores as opposed to others.

We find that households substantially changed their spending as news about the COVID-19's impact in their area spread. Overall, spending increased dramatically in an attempt to stockpile needed home goods and also in anticipation of the inability to patronize retailers. Household spending increases by approximately 50\% overall between February 26 and March 11. Grocery spending remains elevated through March 27, with a 7.5\% increase relative to earlier in the year. We also see an increase in card spending, which is consistent with households borrowing to stockpile goods. As the virus spread and more households stayed home, we see sharp drops in restaurants, retail, air travel and public transport in mid to late March.

Restaurant spending declined by approximately one third. The speed and timing of these increases in spending varied significantly across individuals depending on their geographic location as state and local governments reacted to outbreaks of different sizes and with different levels of urgency. The overall drop in spending is approximately twice as large in states that issued shelterin-place orders, however the increase in grocery spending is three times as large for states with shelter-in-place orders.

We explore heterogeneity among partisan affiliations and demographics, which are closely tied to stated beliefs about the impacts of the new virus. Republicans generally reported less concern about the new virus. For example, an Axios Poll between March 5 and 9 found that $62 \%$ of Republicans thought that the COVID-19 threat was greatly exagerated, while $31 \%$ of Democrats and 35\% of Independents thought the same. A Quinnipac poll between March 5 and 8 also found that $68 \%$ of Democrats were concerned, while only $35 \%$ of Republicans were concerned. Contrary

\footnotetext{
${ }^{1}$ Researchers have previously utilized a range of transaction-level household financial datasets to answer questions about household consumption, liquidity, savings, and investment decisions. See Baker (2018), Baker and Yannelis (2017), Olafsson and Pagel (2018), Baker, Kueng, Meyer and Pagel (2020), and Meyer and Pagel (2019).

${ }^{2}$ For example, see USA Today, CNN, and FoxNews.
} 
to much of what was seen in the press, and despite lower levels of observed social distancing, Republicans actually spent more than Democrats in the early days of the epidemic. We see some significant differences in categorical responses, with Republicans spending more at restaurants and in retail shops, which is consistent with lower levels of concern about the virus or differential risk exposure.

We see significant heterogeneity along demographic characteristics, but little along household income. Households with children stockpiled more, and men stockpiled less in early days as the virus was spreading. We find more spending in later periods by the young. We see little heterogeneity across income, which is largely consistent with work by Kaplan, Violante and Weidner (2014) and Kaplan and Violante (2014) and the "wealthy-hand-to-mouth."

This paper joins a large literature on household consumption. Early empirical work, such as Zeldes (1989), Souleles (1999), Pistaferri (2001), Johnson, Parker and Souleles (2006), Blundell, Pistaferri and Preston (2006) and Agarwal, Liu and Souleles (2007) used survey data or studied tax rebates. Gourinchas and Parker (2002), Kaplan and Violante (2010) and Kaplan and Violante (2014) provide theoretical models of household consumption responses. Recent work uses administrative data (Fuster, Kaplan and Zafar, 2018; Di Maggio, Kermani, Keys, Piskorski, Ramcharan, Seru and Yao, 2017) and Baker (forthcoming), Pagel and Vardardottir (forthcoming) and Baker and Yannelis (2017) have studied income shocks and consumption using financial aggregator data. Jappelli and Pistaferri (2010) provide a review of this literature.

This paper is the first to study how household spending reacts in an epidemic, where there are anticipated income shocks as well as the threat of supply chain disruption, but all combined with significant uncertainty. In early March, there was little direct effect of COVID-19 in the United States, but significant awareness of potential damage in the future. We see significant stockpiling and spending reactions, which is consistent with expectations playing a large role in household consumption decisions.

This paper also relates to a literature on how crises impact the economy, and policy responses to those crises. In the aftermath of the 2008 Great Recession, a large body of work studied how credit supply shocks (Mian and Sufi, 2009, 2011; Mian, Rao and Sufi, 2013) and securitization (Keys, Mukherjee, Seru and Vig, 2008; Keys, Seru and Vig, 2012) led to the financial crisis. Several papers also study the effect of government policies aimed at mitigating the effects of the financial 
crisis. (Bhutta and Keys, 2016; Di Maggio, Kermani, Keys, Piskorski, Ramcharan, Seru and Yao, 2017; Ganong and Noel, 2018). This paper provides a first look at the impacts of the new epidemic on households, which will be key in evaluating any future policy response.

Additionally, the paper joins a growing literature in finance on the impacts of how belief heterogeneity shaped by partisan politics affects real economic decisions. Malmendier and Nagel (2011) show the individuals growing up in the Great Depression exhibited more risk averse behavior relative to others. The literature on how partisanship affects economic decisions has had mixed findings. Some papers have found large effects of partisanship on economic decision-making. For example, Kempf and Tsoutsoura (2018) explore how partisanship affects financial analysts decisions and Meeuwis, Parker, Schoar and Simester (2018) find large effects of the 2016 US Presidential election on portfolio rebalancing. Mian, Sufi and Khoshkhou (2018) study how US presidential elections affect consumption and savings patterns, and find little effect. Baldauf, Garlappi and Yannelis (2020) study how beliefs about climate change impact home prices, and find large differences between political groups. This paper studies differences in partisan behavior in the face of a major crisis where survey evidence indicates large differences in beliefs among people belonging to different political parties, which have been attributed to statements made by policymakers. $^{3}$

Finally this paper joins a rapidly growing body of work studying the impact of the COVID-19 epidemic on the economy. Eichenbaum, Rebelo and Trabandt (2020), Barro, Ursua and Weng (2020) and Jones, Philippon and Venkateswaran (2020) provide macroeconomic frameworks for studying epidemics. Gormsen and Koijen (2020) study the stock price and dividend future reactions to the epidemic, and use these to back out growth expectations for a potential recession caused by the virus. Our paper is the first to study the household spending and debt responses to COVID-19, or any major epidemic, given that detailed high-frequency household financial data did not exist during previous pandemics.

The remainder of this paper is organized as follows. Section 2 describes the main transaction data used in the paper, as well as ancillary datasets. Section 3 discusses the spread of the novel coronavirus in the United States. Section 4 presents the main results, new facts about household

\footnotetext{
${ }^{3}$ A NBC/Wall Street Journal Poll found more Democrats than Republicans were worried about family members catching the virus, while $40 \%$ of Republicans were worried, and that twice as many Democrats thought the virus would change their lives.
} 
spending during an epidemic. Section 5 discusses heterogeneity in spending responses, particularly by partisan affiliation. Section 6 concludes.

\section{Data}

\subsection{Transaction Data}

We analyze de-identified transaction-level data from a non-profit Fintech company. The non-profit Fintech encourages households to increase savings through targeted information and rewards. Users can use the platform to sign up for an account with the non-profit Fintech and link their main bank account including their checking, savings, and credit card accounts. Users have two main incentives for linking accounts. First, the non-profit Fintech can provide them with information, provides tools to aid personal financial decision making and offers financial advice. Second, the non-profit Fintech offers targeted rewards and lotteries to individuals who link their accounts to achieve savings goals.

Figure 1 shows two screenshots of the non-profit Fintech online interface. It shows the screenshots of the main linked account as well as a screenshot of the savings and financial advice resources that the website provides.

The primary data used in this paper consists of de-identified daily data on each user's spending and income transactions from all linked checking, savings, and credit card accounts. In addition, for a large number of users, we are able to link financial transactions to demographic and geographic information. For instance, for most users, we are able to map them to a particular 5-digit zip code. Many users self-report demographic information such as age, education, family size, and the number of children they have. In Panel A of Figure 2, we can see how many users we observe in each US zip code. In Panel B of Figure 2, we show the users' average annual household income by zip code that they report upon signing up with the non-profit Fintech.

Using data from August 2016 to March 2020, we observe bank-account transactions for a total sample of 44,660 users. For each transaction in the data, we observe a category (such as Groceries and Supermarkets or Pharmacies), parent category names (such as ATM), and grandparent category names (such as Shopping and Food). Looking only at the sample of users who have updated their accounts reliably in March of 2020, we have complete data for 4,735 users. These users each 
are required to have several transactions per month in 2020 and have transacted at $\$ 1,000$ in total during these three months of the year.

Table 1 shows monthly summary statistics for users spending in a few select categories as well as their income. We can see that payroll income is relatively low for the median user of the non-profit Fintech, though many users get income from a range of other non-payroll sources. Additionally, we can see the number of linked accounts and number of monthly transactions of users in all linked accounts.

Spending transactions are categorized into a large number of categories and subcategories. For instance, the parent category of 'Shops' is broken down into 53 unique sub-categories including 'Convenience Stores', 'Bookstores', 'Beauty Products', 'Pets', and 'Pharmacies'. For most of our analysis, we examine spending across a majority of categories, excluding spending on things like bills, mortgages, and rent. We also separately focus on a number of individual categories including 'Grocery Stores and Supermarkets' as well as 'Restaurants'.

\subsection{Gallup Daily Tracker Data}

We predict partisanship from 2018 Gallup Daily Tracker Data. Gallup randomly samples 1,000 Americans daily each year via landlines and cellphones. Individuals are asked questions about their political beliefs, expectations about the economy, and demographics. The sample is restricted to individuals 18 and over. We estimate a linear probability model, predicting whether a respondent identifies as a Republican using variables common to both datasets: (i) county (ii) income (iii) gender (iv) marital status (v) presence of children in the household (vi) education and (vii) age. Older people, men, married individuals and individuals with children are more likely to be Republicans. Identifying as a Republican is monotonically increasing in income bins. ${ }^{4}$ The relationship between education and partisan affiliation is non-monotonic, with individuals without a high school diploma strongly leaning Democrat, and individuals with only a high school degree, a vocational degree, or an associates degree being most likely to identify as Republicans.

For each individual we construct a predicted coefficient of partisan leaning, using the coeffi-

\footnotetext{
${ }^{4}$ The Gallup data provides income in bins, rather than in a continuous fashion. We observe self-reported continuous income for the majority of the individuals in the transaction data, for those for whom income is observed in a range we take the midpoint. We standardized the income and education bins in the transaction data to match Gallup to construct out measure of predicted partisanship.
} 
cients estimated from the Gallup data, and predicting partisan learning using demographics in the transaction data. In cases where demographics are missing in the transaction data, we replace the predicted Republican political affiliation with the 2016 Republican vote share, using data from the MIT Election Lab. We classify individuals predicted to be in the top quartile of the highest propensity to be Republicans, and those in the bottom quartile to be Democrats. The remaining individuals in between are classified as Independents.

\subsection{Social distancing data}

We also collect data on the effectiveness of social distancing from unacast.com Unacast social distancing-scoreboard. Unacast provides a daily updated social distancing scoreboard. The scoreboard describes the daily changes in average mobility, measured by change in average distance travelled and the change in non-essential visits using data from tracking smartphones using their GPS signals. The data is available on a daily basis and by county on their website. We use the data of average mobility, because the data on non-essential visits is less reliable as many people have re-located and moved to areas out of a city or kids have moved to parents' homes or vice versa. Therefore, unacast reports the average distance travelled (difference in movement) as the most accurate measure in times of the pandemic. We downloaded the data from their website by day and county and merged it to our consumption data.

\section{Geographic Spread of COVID-19}

COVID-19 was first identified in Wuhan, China before spreading worldwide. This new coronavirus spread very rapidly, and had a mortality rate approximately ten times higher than the seasonal flu and at least twice its infection rates. ${ }^{5}$ The first case in the United States was identified on January 21, 2020 in Washington State, and was quickly followed by cases in Chicago and Orange County, California. All these early cases were linked to travel in Wuhan. Throughout January and February, several cases arose which were all linked to travel abroad. Community transmission was first identified in late February in California. The first COVID-19 linked death occurred on February 29, in Kirkland, Washington. In early March, the first case was identified in New York,

\footnotetext{
${ }^{5}$ See the ADB study referenced by WHO
} 
which by the end of the month would account for approximately half of all identified cases in the United States. In early and mid-March the virus began to spread rapidly.

The federal and many state governments responded to the COVID-19 pandemic in a number of ways. The first state to declare a state of emergency was Washington, which did so on January 30. The following day the US restricted travel from China. Initially, the President made many statements suggesting that the COVID-19 virus was under control. For example, on January 22 President Trump said that the virus was "totally under control" and on February 2nd the President noted that "We pretty much shut it down coming in from China." Statements that the virus was under control continued throughout February, and on February 24 the President said that "The Coronavirus is very much under control in the USA."

This pattern even continued into early March, with the President saying on March 6 that "in terms of cases, it's very, very few." On February 24, President Trump asked Congress for \$1.25 billion in response to the pandemic. General concern and statements from policymakers changed sharply in mid-March as new cases increased rapidly. On March 11, following major outbreaks in Italy and much of Europe, President Trump announced a travel ban on most of Europe. Two days later on March 13, President Trump declared a national emergency. Many states followed by closing schools, restaurants, and bars or issuing shelter-in-place orders.

The fact that the initial public messages about the COVID-19 pandemic were relatively mild and suggested that the panic was under control led to suggestions of a partisan divide on the dangers of the new virus. For example, a NBC/Wall Street Journal Poll between March 11 and 13 found that $68 \%$ of Democrats were worried that someone in their family could catch the virus, while $40 \%$ of Republicans were worried. The same poll found that $56 \%$ of Democrats thought their day-to-day lives would change due the virus, while $26 \%$ of Republicans held the same view. A Pew Research Center Poll between March 10 and 16 found that 59\% of Democrats and 33\% of Republicans called the virus a major threat to US health.

We also worked to obtain data that might predict the extent to which locations are affected by the COVID-19 outbreak as the timing of any household response may differ substantially across geographic regions. As the outbreak has progressed, numerous governments have enacted orders, begun testing regimes, closed schools, and made other statements regarding the extent to which residents of an area should adjust their expectations and behavior. Rather than construct a timeline 
of explicit events, we construct a proxy for the extent to which COVID-19 has impacted a given location at a point in time.

In particular, we gather counts of articles that discuss COVID-19 (or several other related terms like 'corona' or 'coronavirus') across approximately 3,000 US newspapers at a daily level using the Access World News's Newsbank service. We aggregate this data at a state level and look at the ratio of articles related to COVID-19 to the total number of newspaper articles in that state on a given day. This data is displayed for a subset of states in Figure 7 . Figure 7 illustrates differential intensity in reporting on COVID-19 over time across different states. In particular, we see notable increases in reporting in states like Washington prior to other states yet to see major outbreaks.

\section{Household Financial Response to Coronavirus}

While there were media reports of stockpiling, it was not ex ante clear whether consumption would go up or down in the early days of the COVID-19 outbreak. As James Stock notes: "For the week ended March 14, there were two countervailing effects. Consumer confidence plummeted and new claims for unemployment insurance jumped sharply, but same-store sales surged as a result of the run on groceries and supplies."

Figure 3 shows the aggregate response in terms of all daily spending, and grocery spending. The left panel shows average daily spending each week, while the right panel shows average daily grocery spending. After an initial seasonal increase in the first week of the new year, spending is largely flat for most of January and February. There is a sharp spike in spending between February 26 and March 10, as COVID-19 cases begin to spike in the United States. This initial spike in spending is followed by depressed levels of general spending by approximately $50 \%$, but higher levels of grocery spending followed by a sharp drop. This is consistent with stockpiling behavior as it increasingly became clear that there would be a significant number of virus cases in the US. This large and persistent drop is also in line with estimates from surveys conducted by the French Statistical Service, which found a 35\% drop in total consumption.

Figure 4 shows that this initial spike in spending is large and consistent across all categories, however later on there is significant heterogeneity across categories. For some categories, like restaurants, retail, air travel, public transport and card spending. The initial sharp increase in credit 
card spending is consistent with households borrowing to smooth consumption. Food delivery spending increases and remains elevated, not dropping as sharply as other categories.

Figure 5 provides a visualization of the changes in spending between three time periods. The figure shows the percentage change in daily spending across categories, relative to a baseline of January 1 through February 26, 2020. The top panel shows evidence of stockpiling and an increase in consumer spending during the time period when it became clearer that the virus was spreading in the United States. The middle panel shows the change in spending between March 11 and March 17, when a national emergency was initially declared. During this time period, there is a sharp decrease in public transit spending, and continued high levels of elevated spending on groceries and retail.

The bottom panel shows spending between March 18 and March 27, well into shelter-in-place orders in many states. The bottom panel indicates very sharp declines in restaurant spending, air travel, and public transport. There is a significant increase in food delivery spending, consistent with households substituting meals at restaurant with meals at home.

\subsection{Response Across States}

In Table 2, we examine the pattern of user spending in a regression framework, concentrating on the periods of highest interest surrounding the periods between February 26 and March 10, before a national emergency was declared, the period between March 11 and march 17 following the imposition of a national emergency and the period between March 18 and March 27 when states and cities issued shelter-in-place orders. That is, when users seemed to be increasing spending in advance of a 'shelter-in-place' order and when those orders began to take effect.

In each column, we regress users' spending on indicators for the weekly periods indicated: February 26th to March 10, March 11 to March 17, and March 18 to March 27. These periods roughly coincide with observed patterns of behavior among households across the country. In the first period, households tended to be stocking up on goods across a number of categories and also still patronizing entertainment venues and restaurants. The third period, in late March, corresponds to a period in which many cities and states were under 'shelter-in-place' advisories or orders, often with schools closed, non-essential businesses closed, and restaurants forced to only serve take-out food. 
In each column, we present results on user spending with differing samples and types of spending. In columns (1)-(3), we measure user spending using a wide metric that includes services, food and restaurants, entertainment, pharmacies, personal care and transportation. Columns (4)-(6) include only spending on restaurants, while the final set of columns include spending only at grocery stores and supermarkets. In addition, we vary the sample across each column. 'All' represents all users in our sample. 'Shelter' indicates that the sample is limited to users in states that, as of March 27th, had a shelter-in-place order in place. 'No Shelter' restricts to users in states without such an order. All regressions utilize user-level fixed effects and all standard errors are clustered at the user level.

Several clear patterns emerge from this analysis. Overall, we see a stark pattern consistent with the figures presented above. Households tended to stock up substantially at the end of February into the beginning of March, then begin to cut spending dramatically. We also note that the number of transactions followed a similar though less extreme pattern. That is, the number of transactions in the stocking up period increased by about $15 \%$ while spending soared by around $50 \%$. Thus, the size of transactions in the stocking up period was substantially higher than a household's average transaction size.

Comparing users that live in states that have had shelter-in-place orders put in place, we tend to see more negative coefficients in the third row for non-grocery spending (eg. comparing columns (2) and (3) as well as (5) and (6). That is, users in these states tended to decrease spending across categories at a much more rapid pace. This is especially seen within restaurant spending, with users in shelter-in-place states decreasing restaurant spending by about $31.8 \%$, while users in other states decreased restaurant spending by only an insignificant $12.3 \% .^{6}$

In addition, we see more evidence for stocking up on groceries in states that have been put under a shelter-in-place order. Looking at columns (8) and (9), we see that grocery spending has been consistently higher among users in shelter-in-place states, likely reflecting a shift away from eating at restaurants or at office cafeterias and towards eating at home.

\footnotetext{
${ }^{6}$ This decline in restaurant spending is much more muted if we restrict to Fast Food restaurants. Coefficients for these stores are approximately half the size as for non-Fast Food restaurants. This is likely driven by the fact that Fast Food restaurants serve a large portion of their customers via drive through and take out.
} 


\subsection{Response by Social Distancing}

We also link the spending decisions of households to the Unacast data on social distancing, which comes from cell phone records. We create bin scatters (Figure 6) relating the difference in movements to the different spending categories. On the horizontal axis we plot the difference in movement and on the vertical axis we show the log-spending by different categories. In general, we find that across all spending categories a reduction in movement is related to a reduction in spending. The effect size, however, varies by spending category. The less people move the less they spend in restaurants, groceries or on buying at retailers. For public transport we also observe a reduction as less people travel and if they travel they are presumably more likely to use the car. The least reduction is observed for credit card spending. We conjecture this is because the credit card can still be used for online shopping or paying for subscriptions services like Netflix or Apple TV. The data on social distancing underscores the robustness of our findings and clearly relates them to the shelter-in-place orders.

\section{Heterogeneity in Response by Political Views, Demograph- ics, and Financial Indicators}

In Table 3, we split users according to their predicted political orientation and examine how users' spending adjusted during these same periods. In particular, we utilize the Gallup polling data to map demographic and geographic characteristics of these households to form a predicted political score. We split users into the highest and lowest quartiles that are most likely to be Republicans and Democrats, respectively. The specifications mirror those in Table 2, looking at overall spending, restaurant spending, and grocery spending across these different groups.

We noted previously that some categories did see differences in spending changes according to political leanings. Indeed, Figure 9 shows that there was significant heterogeneity in social distancing between more Republican and Democrat leaning states. The figure shows, for each state and the District of Columbia, the overall drop in movement as measured from Unacast cell phone records by the share of the electorate voting for Donald J. Trump in the 2016 US Presidential Election. The figure shows a sharp negative relationship between social distancing and the share of 
Trump voters. States with more Trump voters indicate lower levels of staying at home and social distancing.

We see sharp increases in spending, for both predicted Republicans and Democrats. Contrary to much of the discussion in the popular press and evidence from surveys suggesting that Democrats were more concerned with the virus, we actually see slightly more overall spending between February 26 and March 10 among Republicans relative to Democrats. This is particularly true for grocery spending, which is shown in Figure 10. While we see significant evidence of stockpiling for both groups, the percentage increase in grocery spending by Republicans is approximately twice as large as the increase among Democrats.

The observed differences between predicted Republican and Democrats could be both due to differences in beliefs, and differences in risk exposure. The differences in risk exposure between different partisan groups are not obvious. For example, Republicans are more likely to live in rural areas, while Democrats are more likely to live in urban areas which are at higher risk in a contagion. On the other hand, Republicans also tend to be older, and older individuals are at higher mortality risk from COVID-19.

Figure 3 shows additional categorical spending, broken down by predicted political affiliation. We see a large rise in spending across most categories in early to mid-March, consistent with stockpiling. Republicans are more likely to continue to spend at shops, and while this difference persists, it may be driven by differential geographic patterns if Republicans live in more rural areas that offer fewer home delivery services, and more drive-up options. Consistent with some differential spending patterns being driven by geographic and urbanization patterns, the drop in public transportation and air travel is driven almost entirely by Democrats, as Republicans are much less likely to use public transportation ex ante. All groups increase their utilization of food delivery services.

Finally, in Table 4, we examine how user spending responses differed across some key demographic and financial characteristics. We again perform a similar regression analysis, here interacting the weekly indicators with indicators of whether a household possessed a demographic or financial characteristic. Notably, we include interactions for whether the user is under 30 years old, whether they have children, whether they are male, and whether they have an annual income above $\$ 40,000$. Across the three panels, we again turn to looking at a wide measure of users' spending, 
just restaurant spending, and just spending at grocery stores and supermarkets.

In the first column, we see that younger users tended to cut back on spending by a smaller amount than older users. This coincides with reports that younger individuals were obeying the shelter-in-place orders less strictly than older Americans. We see the same pattern in restaurant spending, though the interaction is not significantly different than zero.

In the second column, we find that households with children tended to have the largest declines in spending in recent days, with overall spending falling around twice as fast as among households without children. We also note that, in Panel C, we find that households with children tended to increase grocery spending in the earlier weeks of the outbreak by significantly more than users with no children.

In column (3), we see that male users tended to have more muted responses in most categories. That is, men generally 'stocked up' less than women in the early weeks of March, and also cut back spending less than women did in the later weeks. Finally, the last column looks at differential behavior among users with higher income. In general, here we see few differences. Users with high income tended to behave quite similarly in their patterns of spending behavior to users with lower income. This is largely consistent with work by Kaplan, Violante and Weidner (2014) and Kaplan and Violante (2014) and there being a significant number of "wealthy-hand-to-mouth" consumers.

\section{Conclusion}

This paper provides a first view of household spending during the recent weeks of the COVID-19 outbreak in the United States. Using transaction-level household financial data from a personal financial website, we illustrate how Americans' spending responded to the rise in disease cases as well as to the policy responses put in place by many city and state governments, namely shelterin-place orders. We show that users' spending was radically altered by these events across a wide range of categories, and that the strength of the response partly depended on how severe the outbreak was in a user's state. Demographic characteristics such as age and family structure provoked larger levels of heterogeneity in spending responses to COVID-19, while income did not. Moreover, we demonstrate users of all political orientation increased spending prior to the epidemic, and at the same time there were some differences across political orientation in some categories 
indicative of differential beliefs or risk exposure.

We caution that these are very short term responses, meant to illustrate as close to a real-time view of consumer spending as possible. In part, this paper demonstrates the utility of household transaction level data in providing a window into not just household finance, but also aggregate trends, as well. Additionally, we caution that our data are skewed towards younger users, who have lower risk exposure. Older individuals with very high risk exposure may have behave differently, and cut consumption more substantially.

The COVID-19 outbreak has upended economies around the world and we are surely just at the beginning of understanding the full impact at both a household and national level. We anticipate large amounts of future work examining the impact of COVID-19 using household transaction data. Questions about how households went about rearranging spending, shifted from brick and mortar to online retailers, and utilized liquidity and credit are all at the forefront. Moreover, the ability to observe household-level income and the sources of this income may be fruitful in analyzing how households who faced sudden unemployment were able to substitute to new types of work and new employers. For example, disemployed retail workers might find fast employment in sectors with newly elevated demand, such as home delivery services. 


\section{References}

Agarwal, Sumit, Chunlin Liu, and Nicholas S Souleles, "The Reaction of Consumer Spending and Debt to Tax Rebates- Evidence from Consumer Credit Data," Journal of Political Economy, 2007, 115 (6), 986-1019.

Baker, Scott R., "Debt and the Response to Household Income Shocks: Validation and Application of Linked Financial Account Data," Journal of Political Economy, 2018.

_ , "Debt and the Consumption Response to Household Income Shocks," Journal of Political Economy, forthcoming.

_ and Constantine Yannelis, "Income Changes and Consumption: Evidence from the 2013 Federal Government Shutdown,” Review of Economic Dynamics, 2017, 23, 99-124.

_ , Lorenz Kueng, Steffen Meyer, and Michaela Pagel, "Measurement Error in Imputed Consumption," Working Paper, 2020.

Baldauf, Markus, Lorenzo Garlappi, and Constantine Yannelis, "Does Climate Change Affect Real Estate Prices? Only If You Believe In It,” The Review of Financial Studies, 2020, 33 (3), $1256-1295$.

Barro, Robert J, José F Ursua, and Joanna Weng, "The Coronavirus and the Great Influenza Epidemic," 2020.

Bhutta, Neila and Ben Keys, "Household Credit and Employment in the Great Recession," American Economic Review, 2016, 106 (7), 1742-74.

Blundell, Richard, Luigi Pistaferri, and Ian Preston, "Consumption Inequality and Partial Insurance," American Economic Review, 2006, 98 (5), 1887-1921.

Eichenbaum, Martin S, Sergio Rebelo, and Mathias Trabandt, "The Macroeconomics of Epidemics,” Technical Report, National Bureau of Economic Research 2020.

Fuster, Andreas, Greg Kaplan, and Basit Zafar, "What Would You Do With \$500? Spending Responses to Gains, Losses, News and Loans," Technical Report, National Bureau of Economic Research 2018.

Ganong, Peter and Pascal Noel, "Liquidity vs. Wealth in Household Debt Obligations: Evidence from Housing Policy in the Great Recession," Technical Report, National Bureau of Economic Research 2018. 
Gormsen, Niels Joachim and Ralph SJ Koijen, "Coronavirus: Impact on Stock Prices and Growth Expectations," University of Chicago, Becker Friedman Institute for Economics Working Paper, 2020, (2020-22).

Gourinchas, Pierre-Olivier and Jonathan A. Parker, "Consumption Risk Over the Life-Cycle," Econometrica, 2002, 70 (1), 47-89.

Jappelli, Tullio and Luigi Pistaferri, “The Consumption Response to Income Changes,” Annual Review of Economics, 2010, 2, 479-506.

Johnson, David S., Jonathan A. Parker, and Nicholas Souleles, "Household Expenditure and the Income Tax Rebates of 2001," American Economic Review, 2006, 96 (5), 1589-1610.

Jones, Callum, Thomas Philippon, and Venky Venkateswaran, "Optimal Mitigation Policies in a Pandemic," Working Paper, 2020.

Kaplan, Greg and Gianluca Violante, "How Much Consumption Insurance beyond SelfInsurance?," American Economic Journal: Macroeconomics, 2010, 2 (4), 53-87.

_ and _, "A Model of the Consumption Response to Fiscal Stimulus Payments," Econometrica, 2014, 82 (4), 1199-1239.

_ , Giovanni L Violante, and Justin Weidner, “The Wealthy Hand-to-Mouth,” Brookings Papers on Economic Activity, 2014, p. 77.

Kempf, Elisabeth and Margarita Tsoutsoura, "Partisan Professionals: Evidence from Credit Rating Analysts,” Technical Report, National Bureau of Economic Research 2018.

Keys, Benjamin, Amit Seru, and Vikrant Vig, "Lender Screening and the Role of Securitization: Evidence from Prime and Subprime Mortgage Markets," Review of Financial Studies, 2012, 25 (7), 2071-2108.

_, Tanmoy Mukherjee, Amit Seru, and Vikrant Vig, "Did Securitization Lead to Lax Screening? Evidence from Subprime Loans," Quarterly Journal of Economics, 2008, 125 (1), 307-362.

Maggio, Marco Di, Amir Kermani, Benjamin J Keys, Tomasz Piskorski, Rodney Ramcharan, Amit Seru, and Vincent Yao, "Interest Rate Pass-through: Mortgage Rates, Household Consumption, and Voluntary Deleveraging," American Economic Review, 2017, 107 (11), 3550-88.

Malmendier, Ulrike and Stefan Nagel, "Depression Babies: Do Macroeconomic Experiences Affect Risk Taking?," The Quarterly Journal of Economics, 2011, 126 (1), 373-416. 
Meeuwis, Maarten, Jonathan A Parker, Antoinette Schoar, and Duncan I Simester, "Belief Disagreement and Portfolio Choice," Technical Report, National Bureau of Economic Research 2018.

Meyer, Steffen and Michaela Pagel, "Fully Closed: Individual Responses to Realized Gains and Losses," Working Paper, 2019.

Mian, Atif and Amir Sufi, "The Consequences of Mortgage Credit Expansion: Evidence from the US Mortgage Default Crisis," The Quarterly Journal of Economics, 2009, 124 (4), 9-49.

_ and _ ,"House Prices, Home Equity-Based Borrowing and the US Household Leverage Crisis," American Economic Review, 2011, 101 (5), 2132-56.

_ , Kamalesh Rao, and Amir Sufi, "Household Balance Sheets, Consumption and the Economic Slump," The Quarterly Journal of Economics, 2013, 128 (4), 1687-1726.

Mian, Atif R, Amir Sufi, and Nasim Khoshkhou, "Partisan Bias, Economic Expectations, and Household Spending," Fama-Miller Working Paper, 2018.

Olafsson, Arna and Michaela Pagel, “The Liquid Hand-to-Mouth: Evidence from Personal Finance Management Software," Review of Financial Studies, 2018.

Pagel, Michaela and Arna Vardardottir, "The Liquid Hand-to-Mouth: Evidence from a Personal Finance Management Software," Review of Financial Studies, forthcoming.

Pistaferri, Luigi, "Superior Information, Income Shocks and the Permanent Income Hypothesis," Review of Economics and Statistics, 2001, 83 (3), 465-476.

Souleles, Nicholas, "The Response of Household Consumption to Income Tax Refunds," American Economic Review, 1999, 89 (4), 947-958.

Zeldes, Stephen, “Consumption and Liquidity Constraints: An Empirical Investigation,” Journal of Political Economy, 1989, 97 (2), 1469-1513. 
Figure 1: Example of Platform

Notes: Screenshots of the app and its financial advice page. Source: Non-Profit Fintech.

Hi, Michaela

MYSAVINGS

$\$ 1,332.00$

$+\$ 0.00$ this month

Scratch \& Save (i)

Tax Time Pledge (i)

$\square 36$ days left

Take the

Pledge

Saved $\$ 0$ of $\$ 5$

for points \&
prizes

Tax Time Story

Win up to

$\$ 5,000$ by

uploading a

picture of a

yoursef and sharing what

Share my story

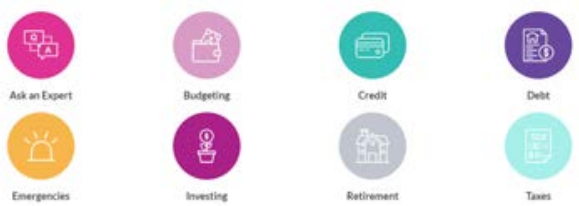




\section{Figure 2: Non-Profit Fintech Users}

Notes: Panel A displays the number of the non-profit Fintech users by 5-digit zip code in the US. Panel B shows the average annual self-reported income of users by 5-digit zip code in the US (in 1,000 USD). Source: Non-Profit Fintech.

Panel A: Number of Users Number of users by 5-digit zip code

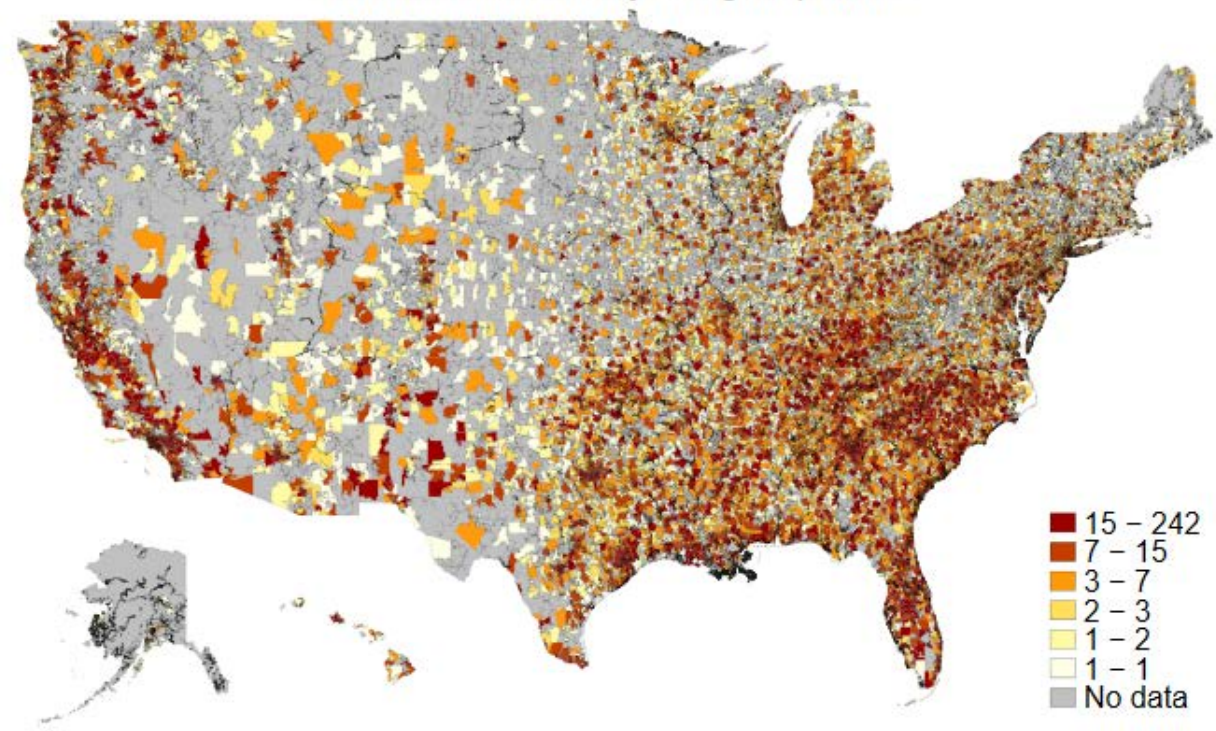

Panel B: Average User Income

Average annual household income by 5-digit zip code in 1,000 USD

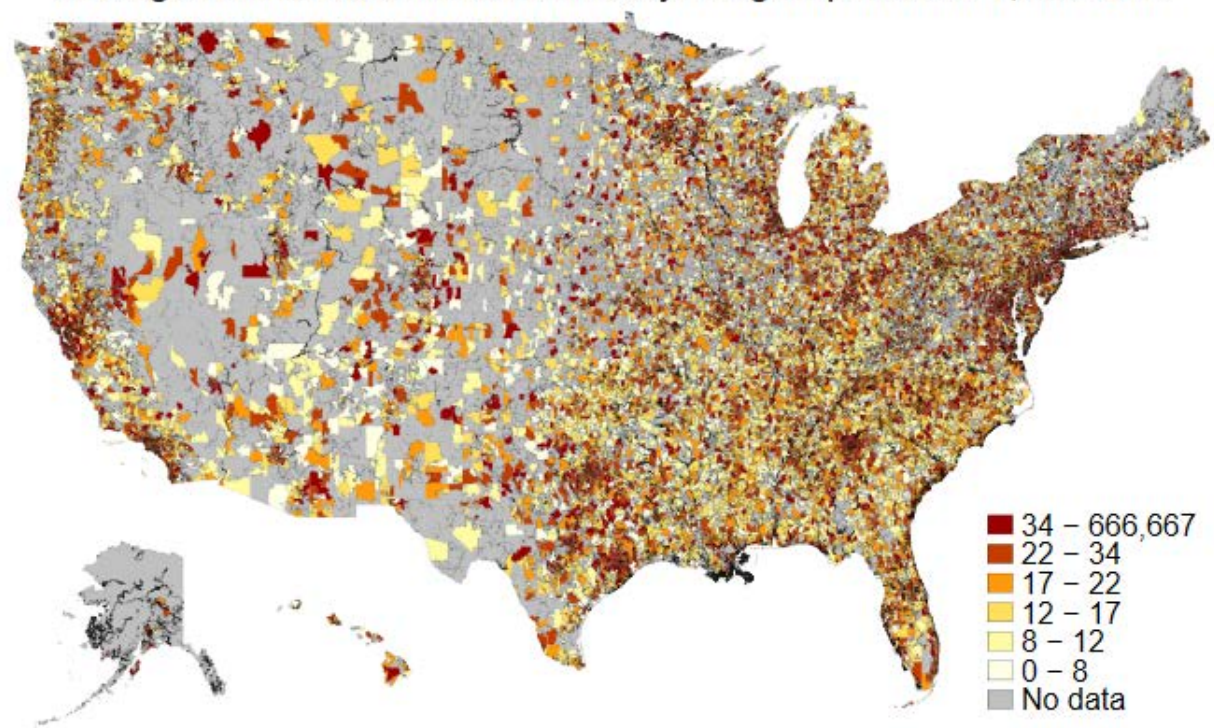




\section{Figure 3: Household Grocery Spending Response}

Notes: This graph displays how household spending changed by week in 2020. Spending is measured in daily dollars. Months are split into four periods equal in size across months. Individual fixed effects are removed prior to collapsing across individuals. Source: Non-Profit Fintech.

\section{All Spending}

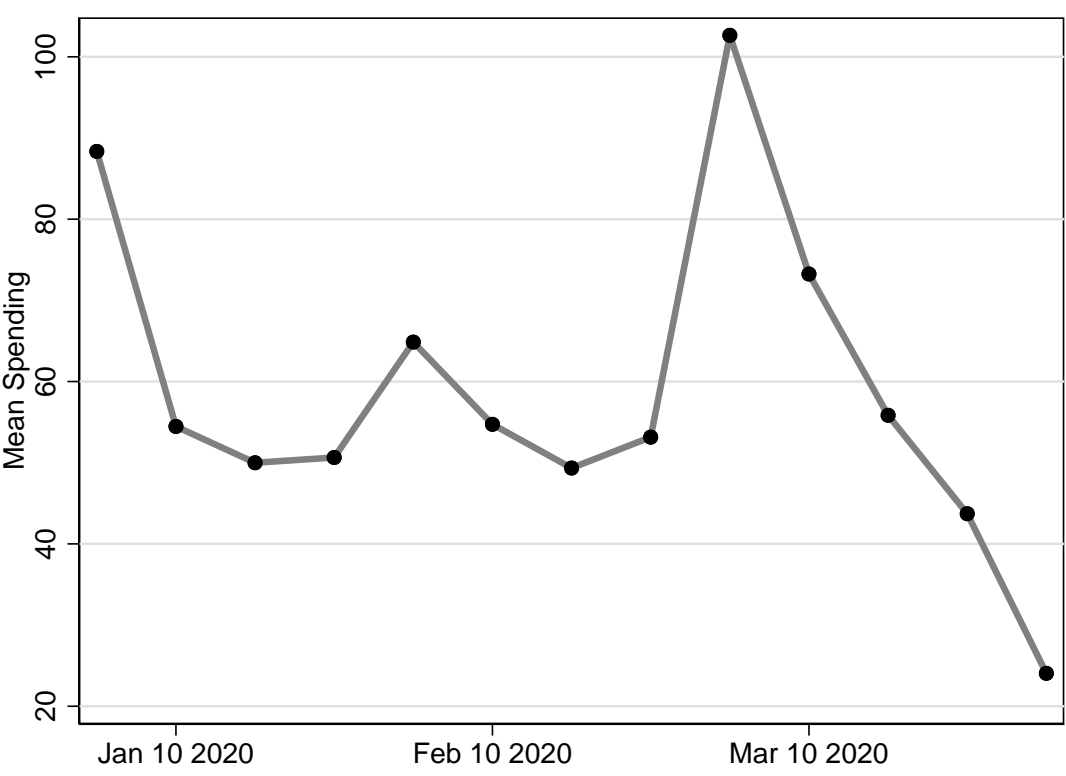

Grocery Spending

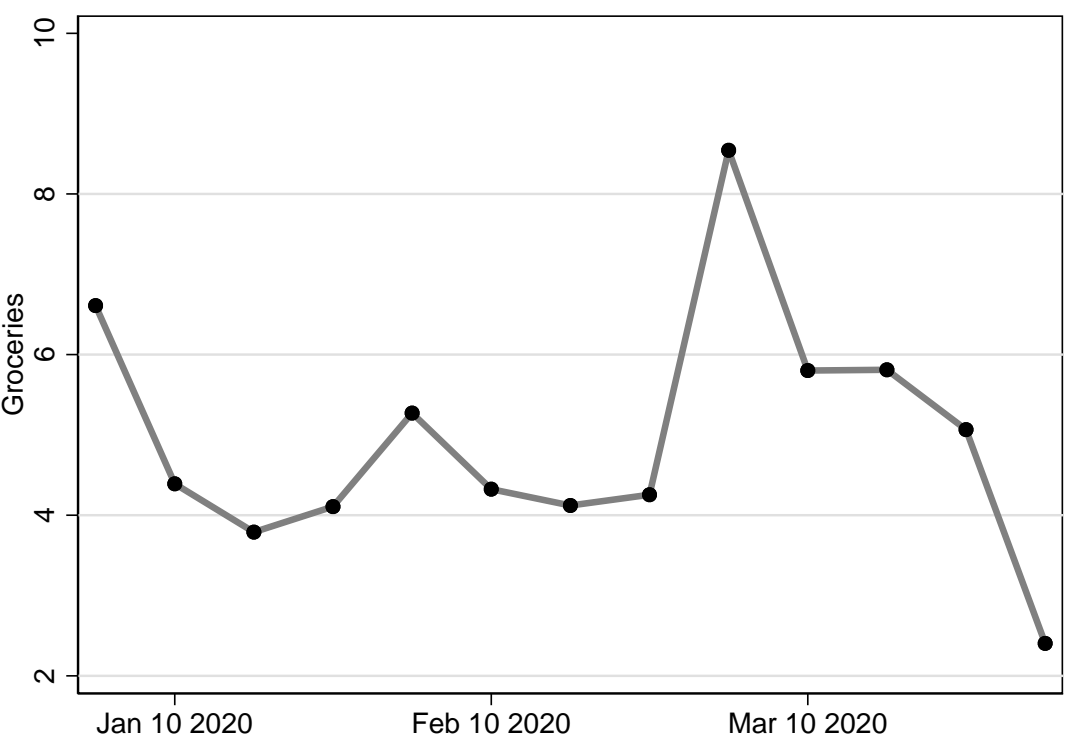




\section{Figure 4: Household Spending Response Across Categories}

Notes: This graph displays the response of household spending across a number of categories of spending. Spending is measured in daily dollars. Estimates are taken as the change in household spending from the first week of February to the first week of March. Source: Non-Profit Fintech.

Retail Spending

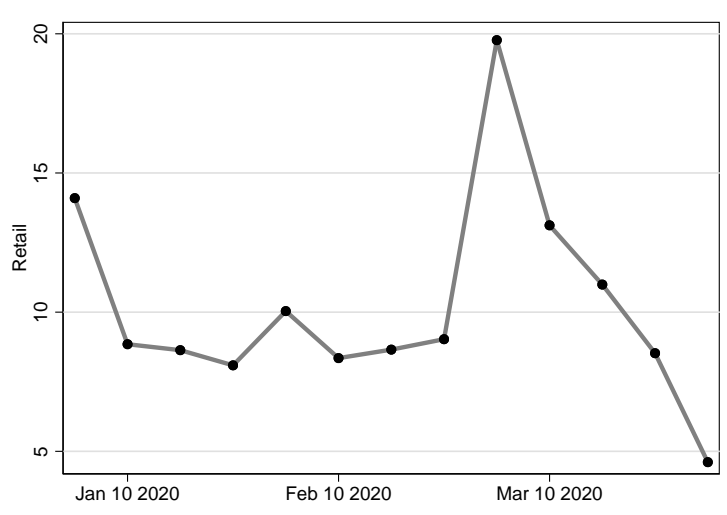

Food Delivery Spending

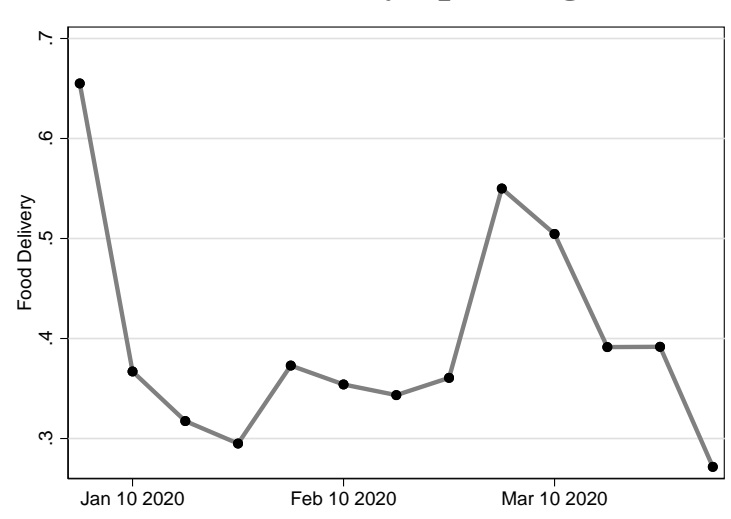

Restaurant Spending

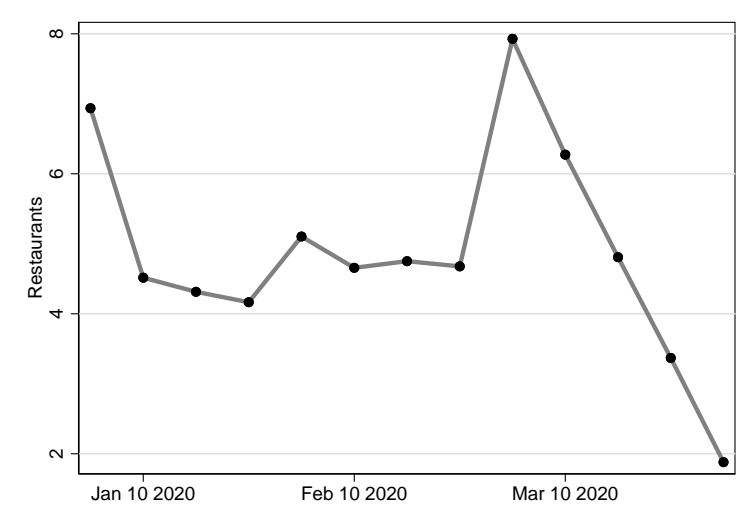

Public Transit Spending

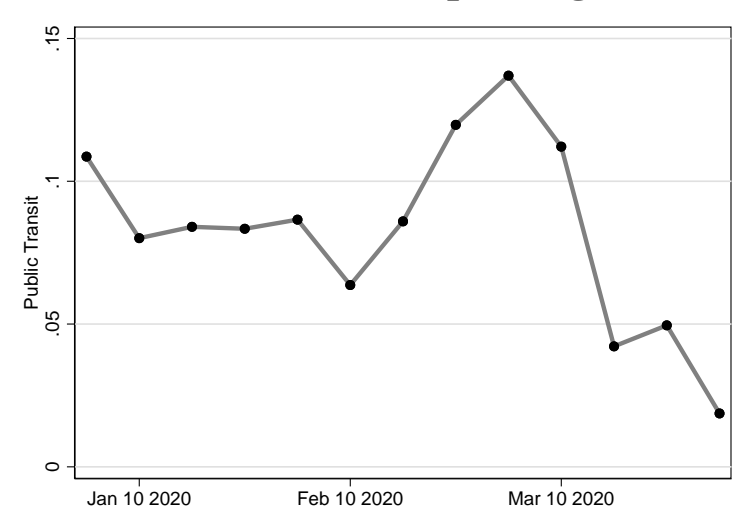

Air Travel Spending

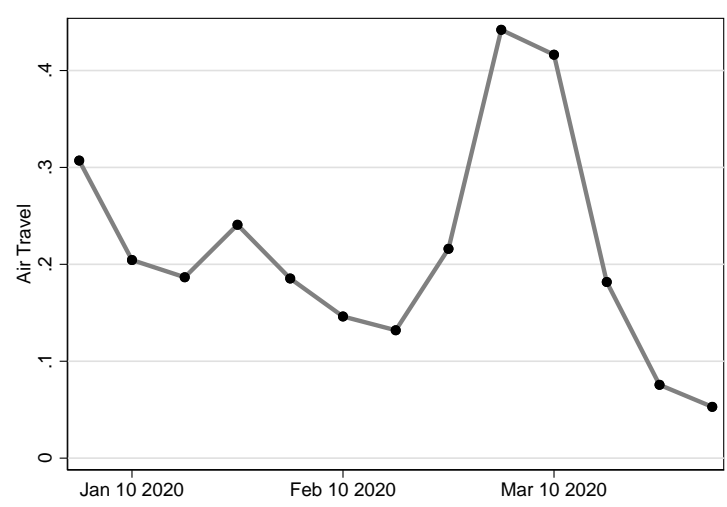

Credit Card Spending

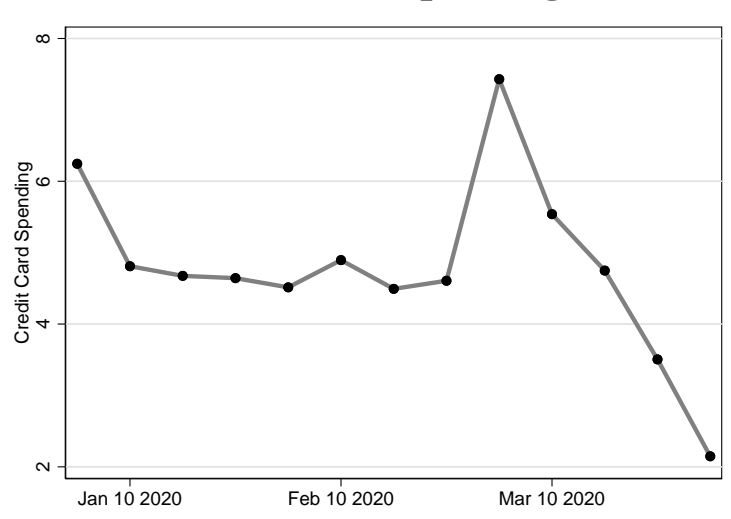




\section{Figure 5: Household Spending Response Across Categories}

Notes: This figure displays the percentage change in mean daily spending, across different categories relative to spending pre-February 26. Source: Non-Profit Fintech.
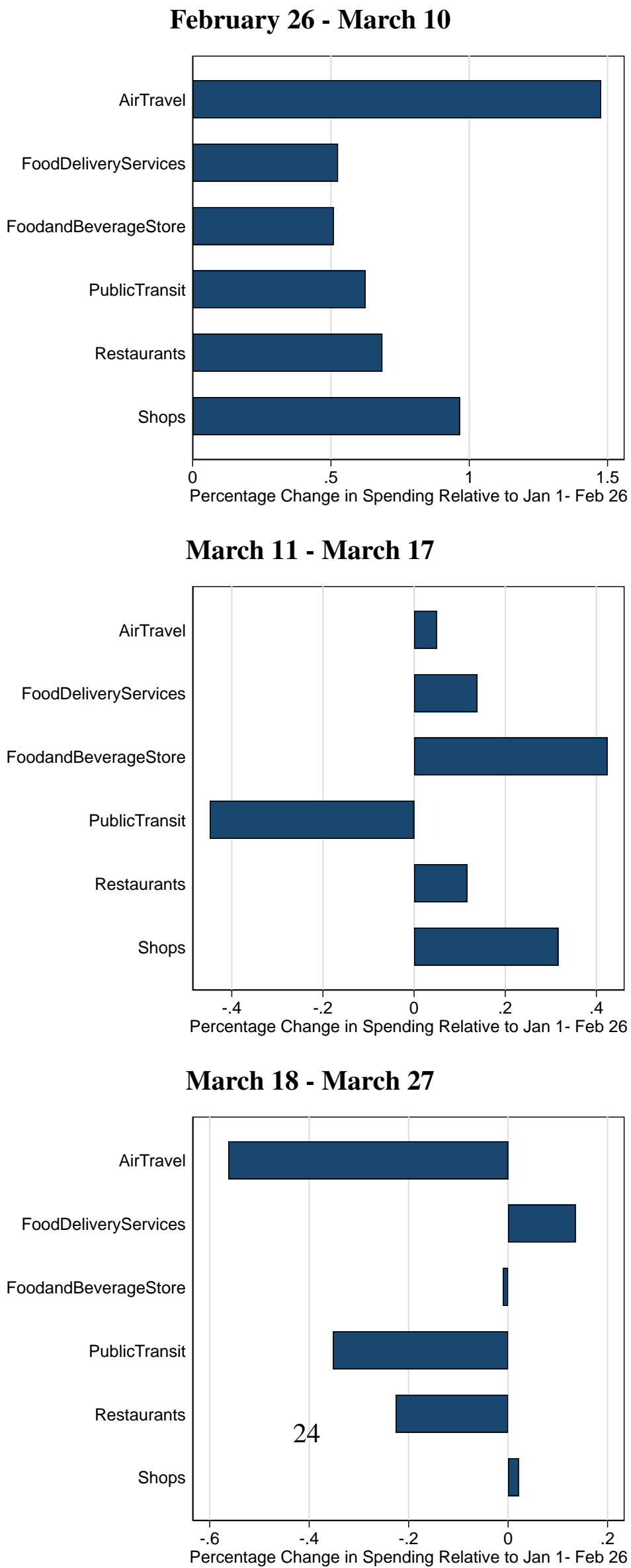
Figure 6: Household Spending and Social Distancing

Notes: This graph displaysf household spending across a number of categories of spending in bins of the daily difference in movement. Spending is measured in daily dollars. Source: Non-Profit Fintech and Unacast.

Total Spending

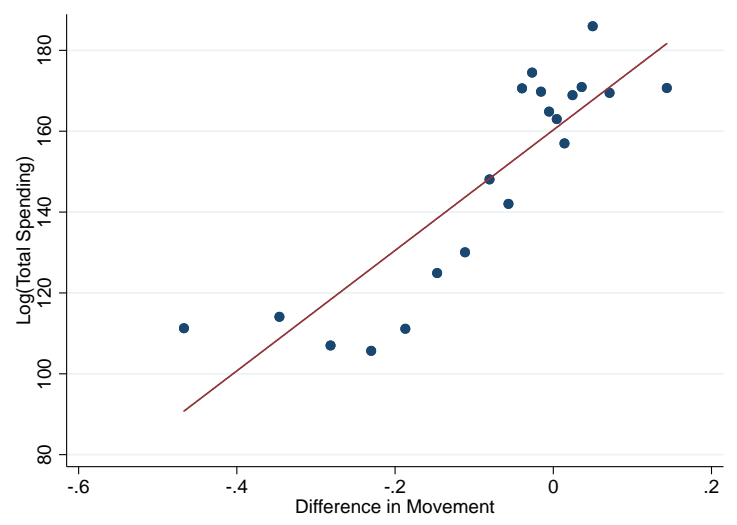

Retail Spending

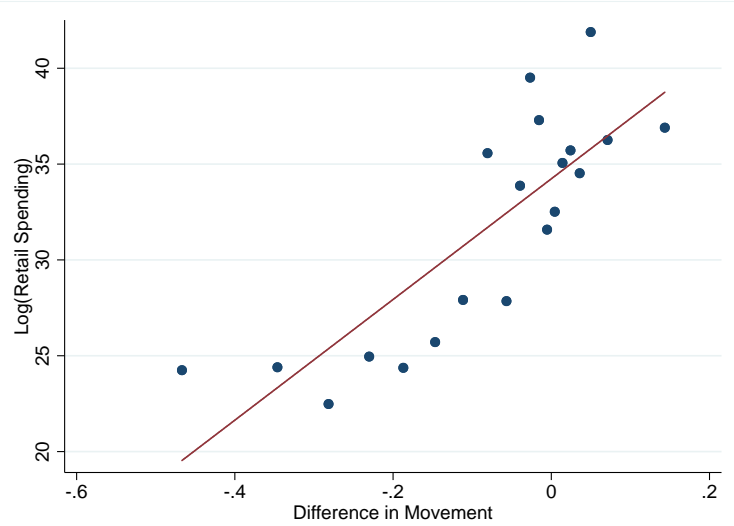

Credit Card

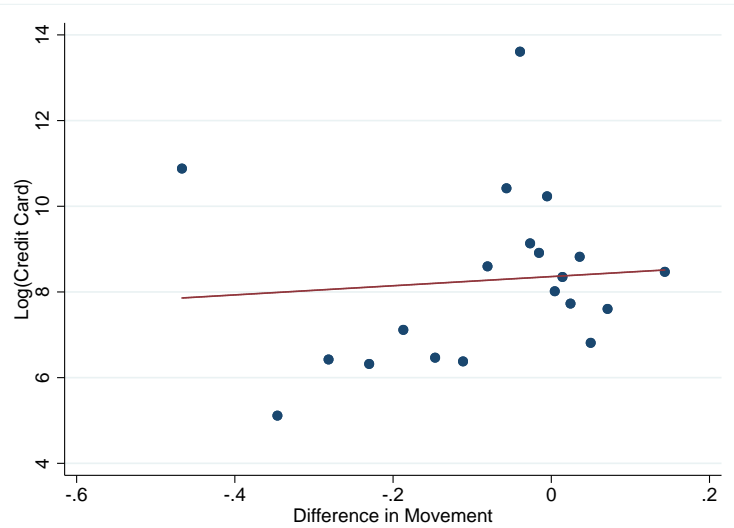

Grocery Spending

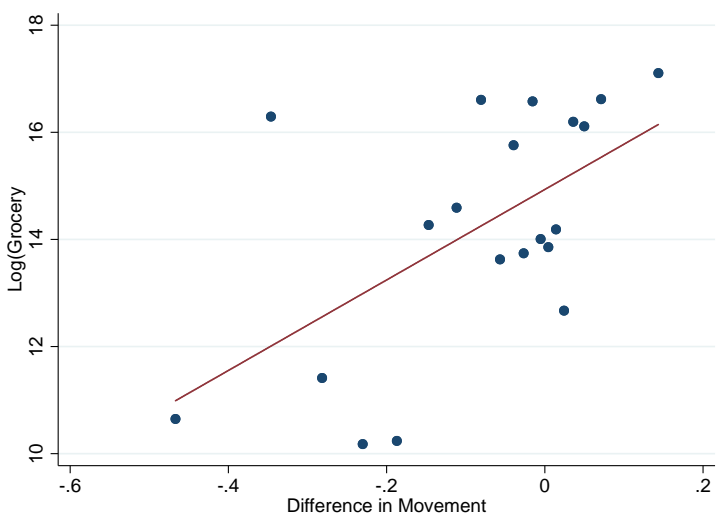

Restaurant Spending

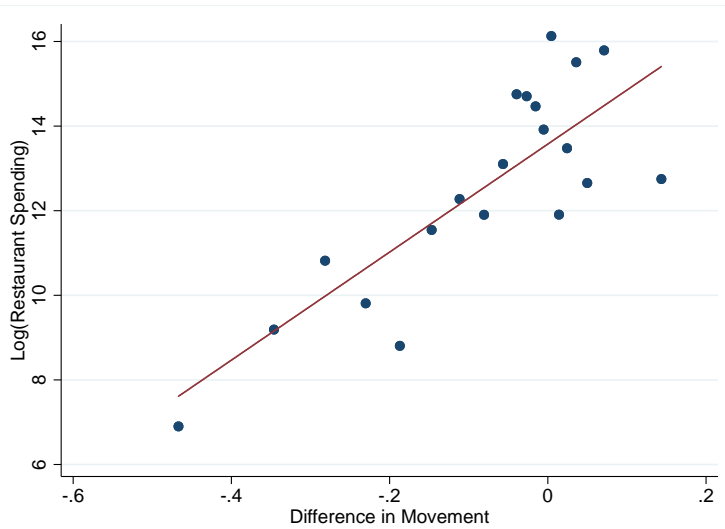

Public Transport

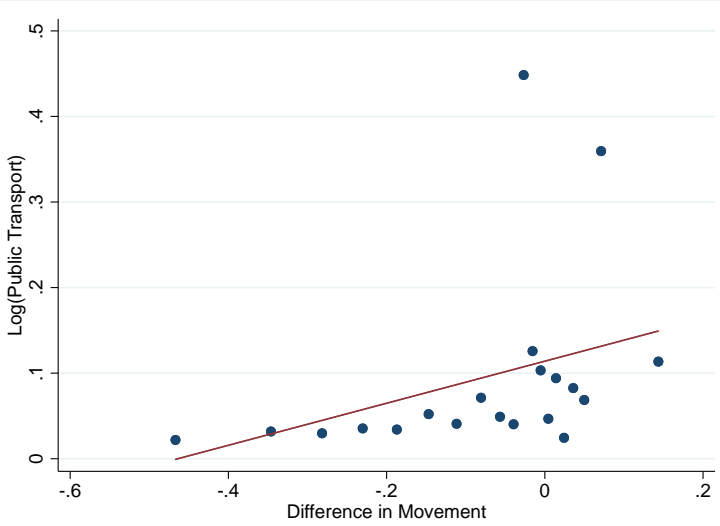




\section{Figure 7: Newspaper Coverage of COVID-19, by State}

Notes: This graph displays the fraction of newspaper articles in US newspapers that mentions a term related to COVID-19. Data shown for selected states. Nationwide, over 3,000 newspapers are utilized.

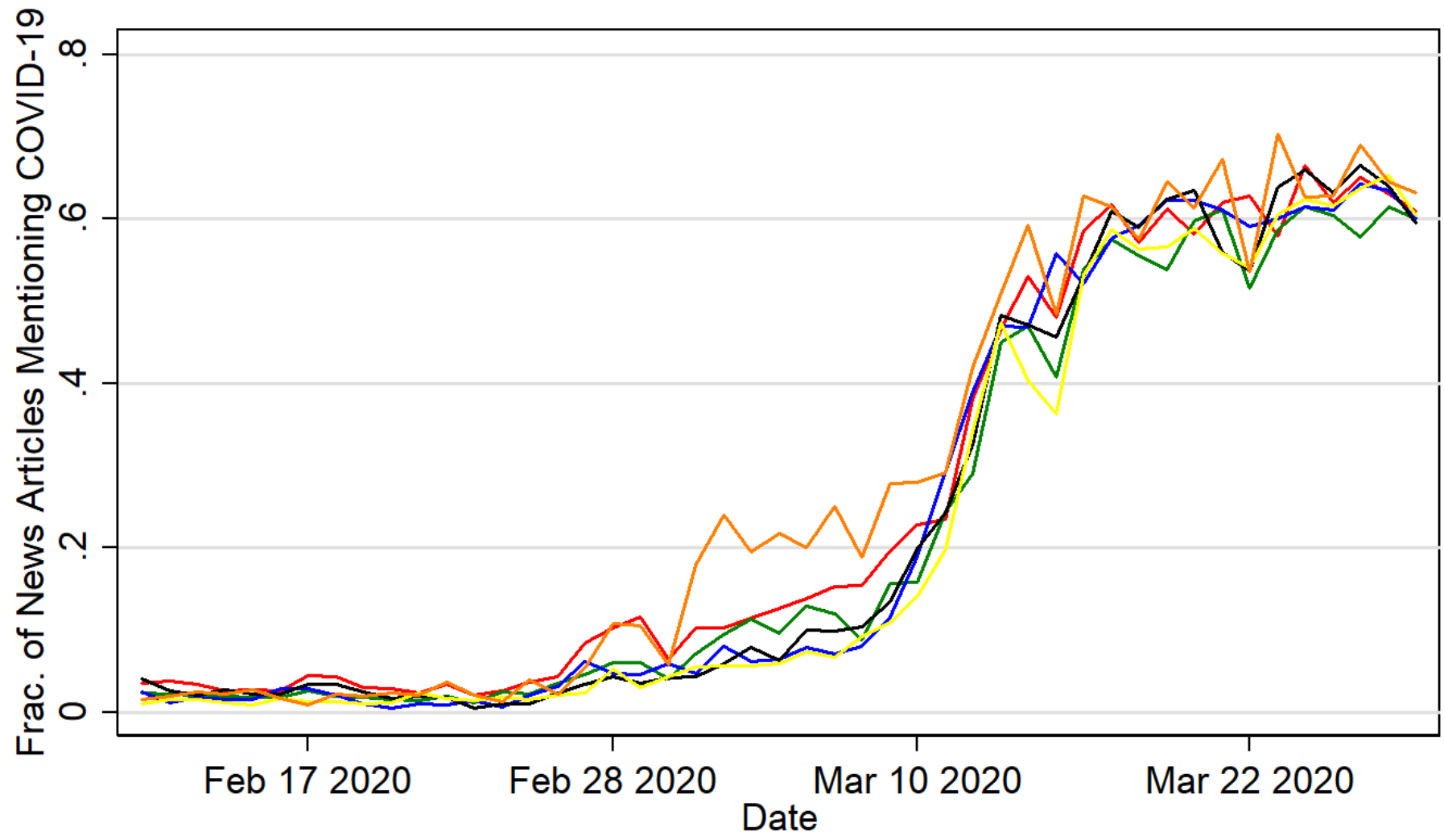

\begin{tabular}{cl}
\hline California & New York \\
Ohio & Pennsylvania \\
Texas & Washington \\
\hline
\end{tabular}




\section{Figure 8: Map of Average Partisanship, by County}

Notes: This figure shows the average predicted partisan scores in US counties. Darker red shapes indicates more Republican countries, while darker blue shades indicate more Democrat counties. Source: Gallup

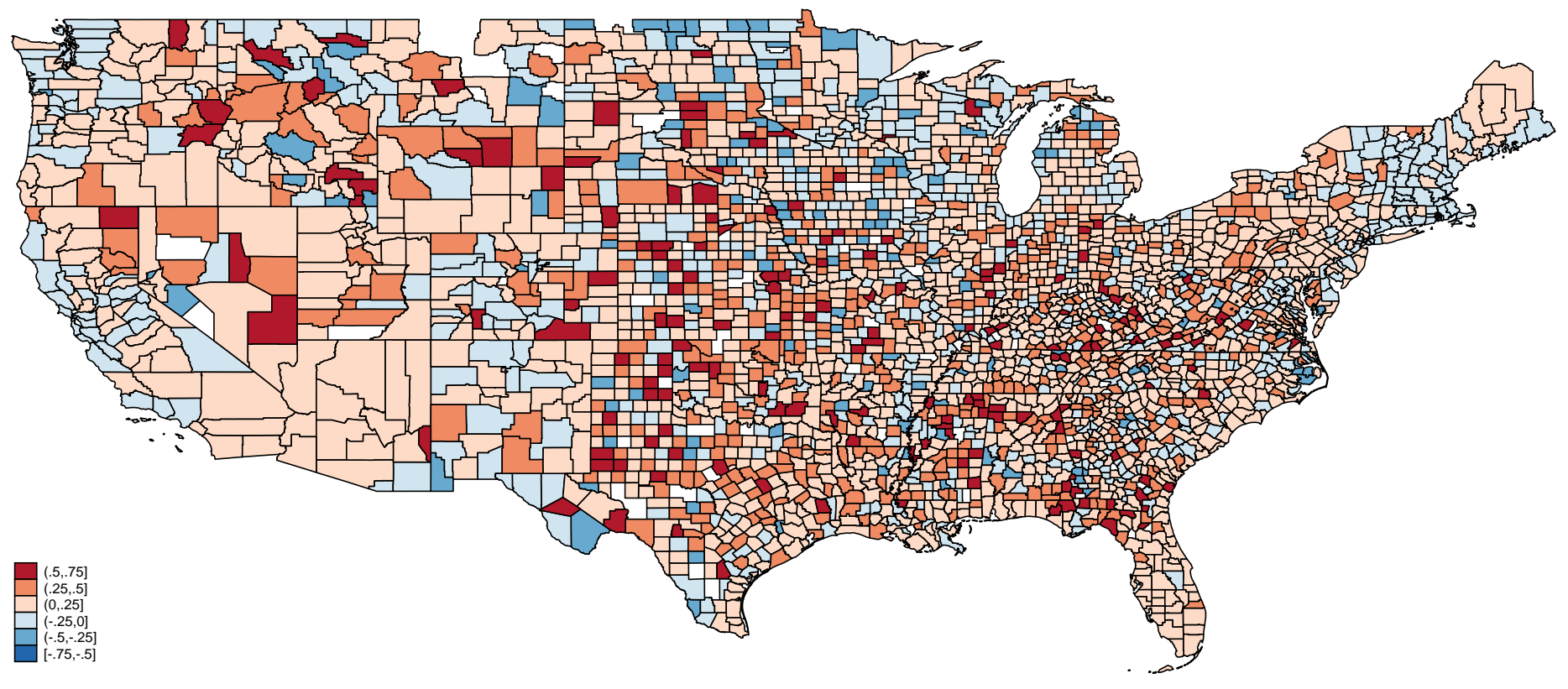




\section{Figure 9: Vote Shares and Social Distancing Efforts}

Notes: This figure shows a binned scatter plot of the drop in movement in all 50 US states and the District of Columbia, and the fraction of individuals who voted for Donald Trump in the 2016 US Presidential election. Source: MIT Election Data Lab and Unacast Social Distancing Scoreboard.

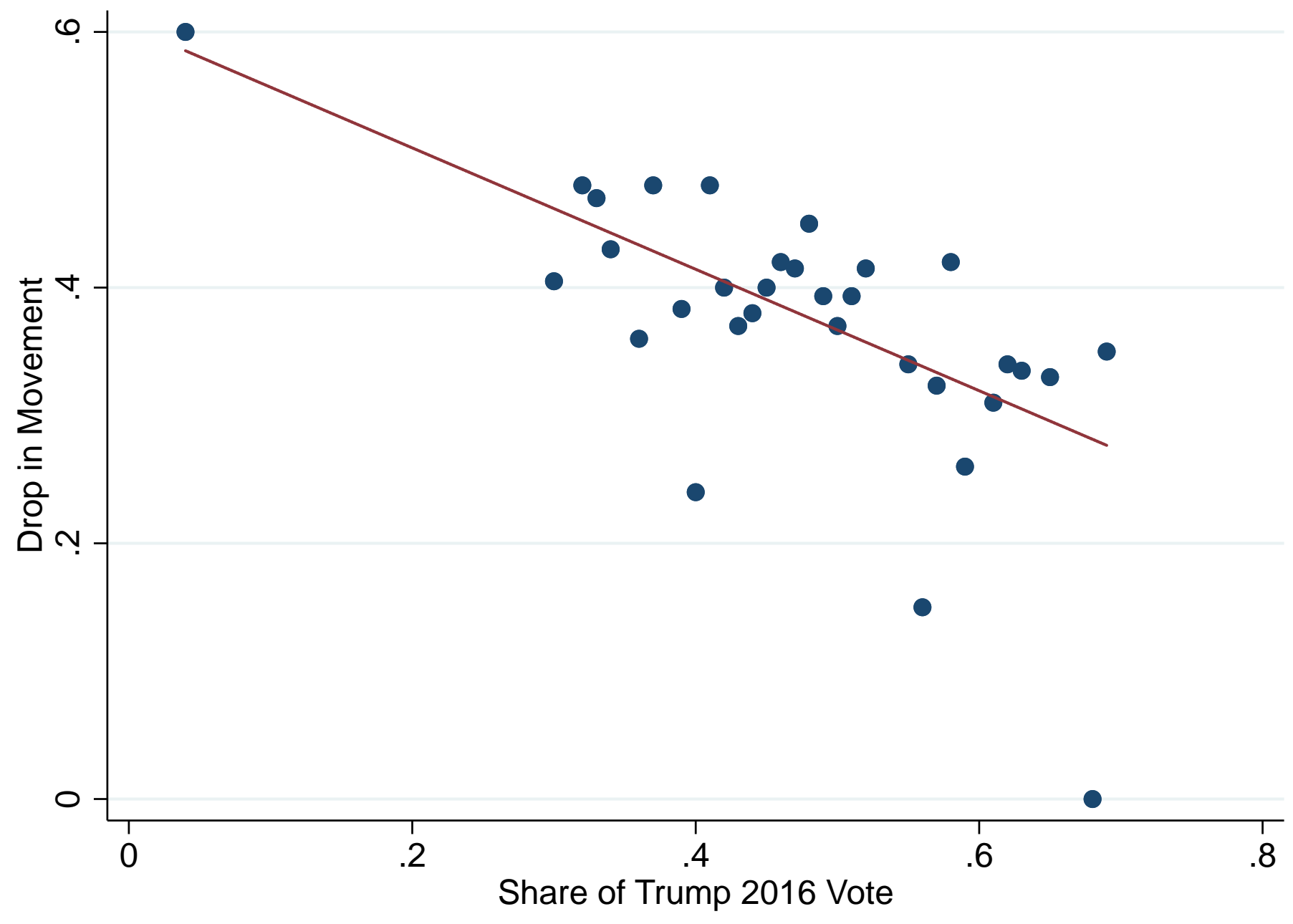


Figure 10: Grocery Spending and Political Scores in 2020

Notes: This figure displays the response of average household daily spending for groceries. Estimates are taken as the change in household spending from the first week of February to the first week of March. For each category, average response is plotted for three groups: the quartile of the sample with the highest predicted 'democrat' lean and the quartile of the sample with the highest predicted 'republican' lean and 'independents' who are in the middle two quartiles. Spending is measured in daily dollars. Source: Non-Profit Fintech.
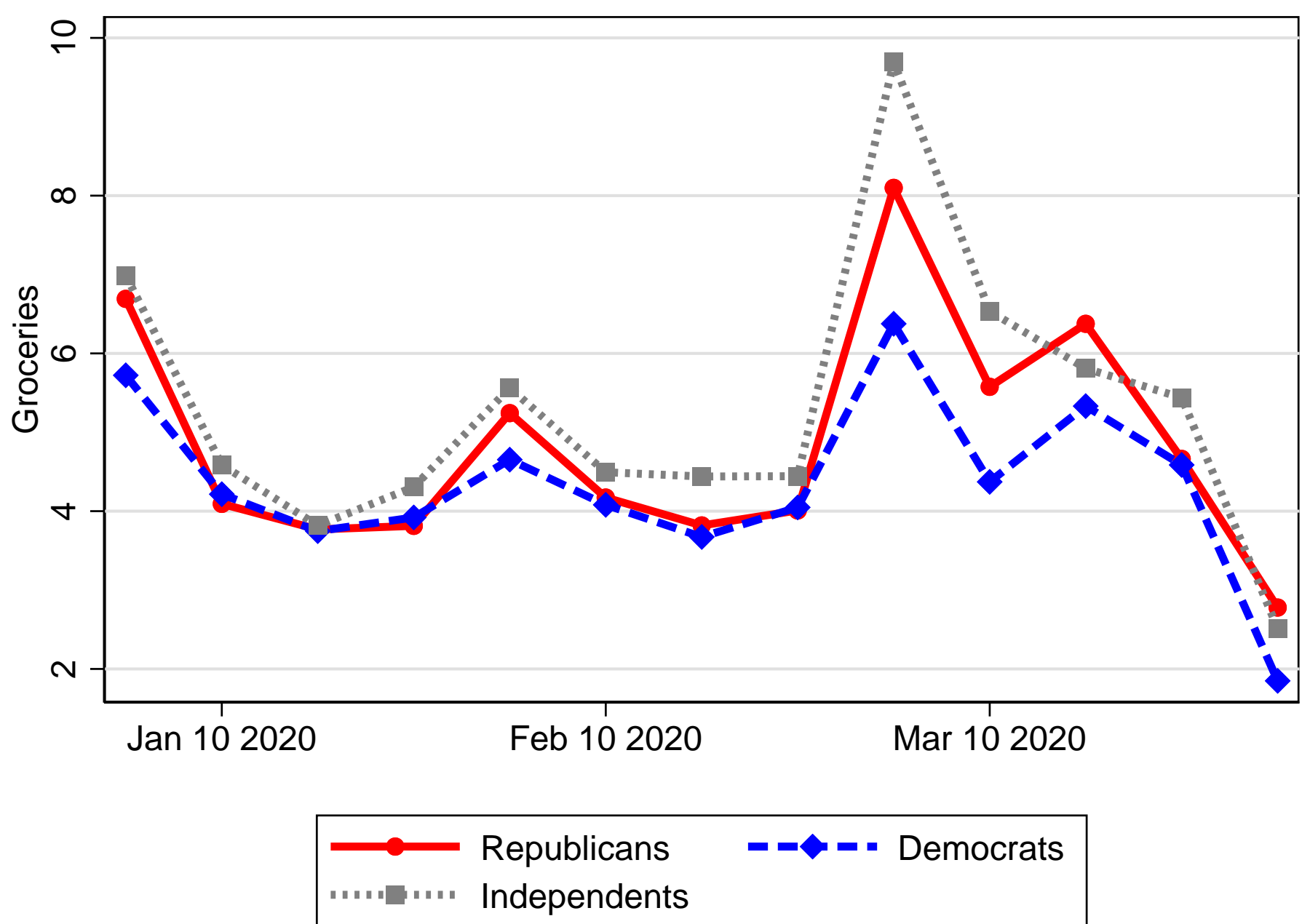


\section{Figure 11: Household Spending Response Across Categories, by Predicted Partisanship}

Notes: This figure displays the response of average household daily spending across a number of categories of spending. Estimates are taken as the change in household spending from the first week of February to the first week of March. For each category, average response is plotted for three groups: the quartile of the sample with the highest predicted 'democrat' lean and the quartile of the sample with the highest predicted 'republican' lean and 'independents' who are in the middle two quartiles. Spending is measured in daily dollars. Source: Non-Profit Fintech.

Retail Spending

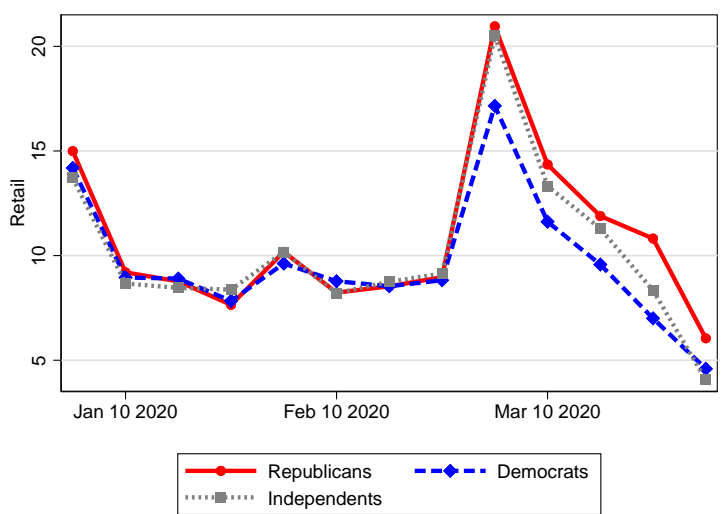

Food Delivery Spending

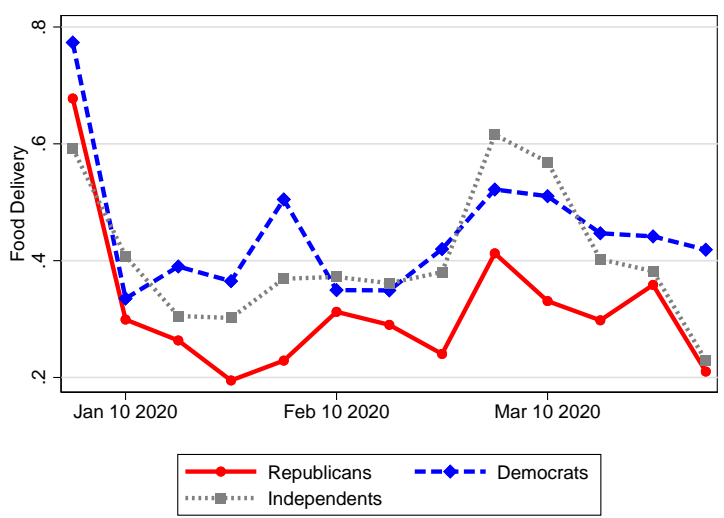

Restaurant Spending

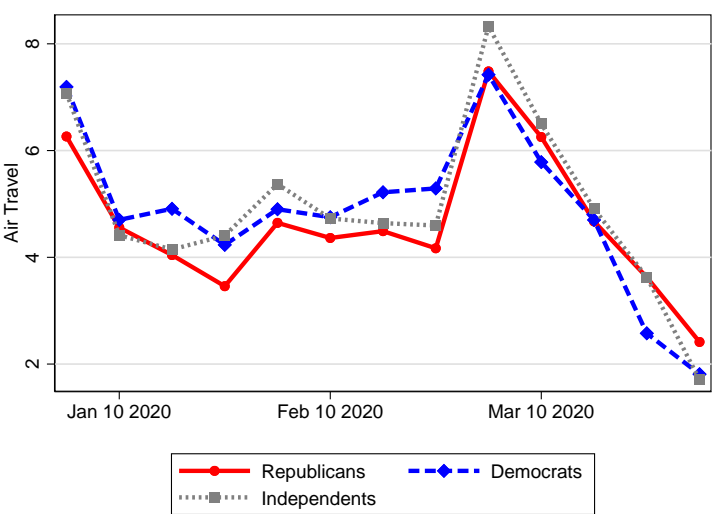

Public Transit Spending

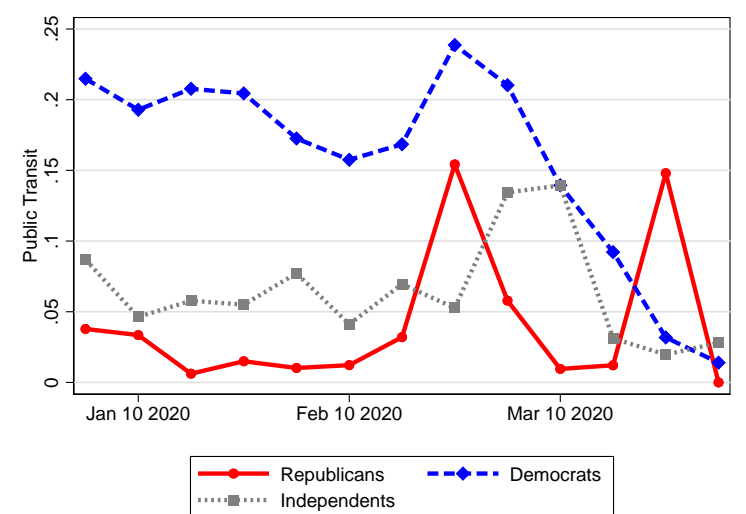

Air Travel Spending

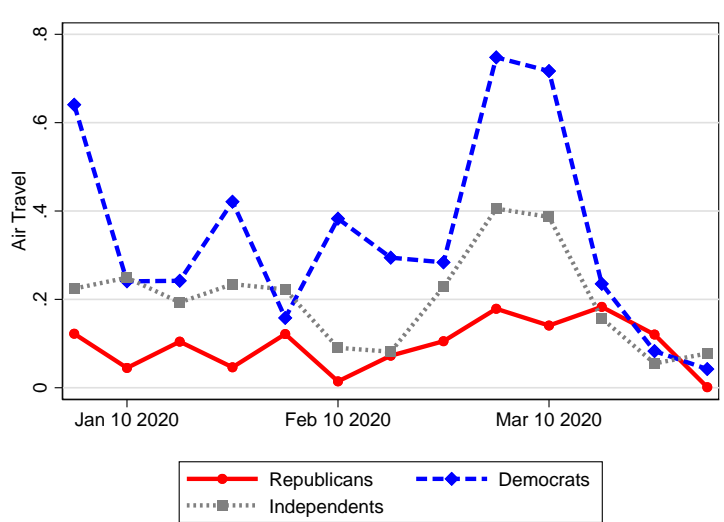

Credit Card Spending

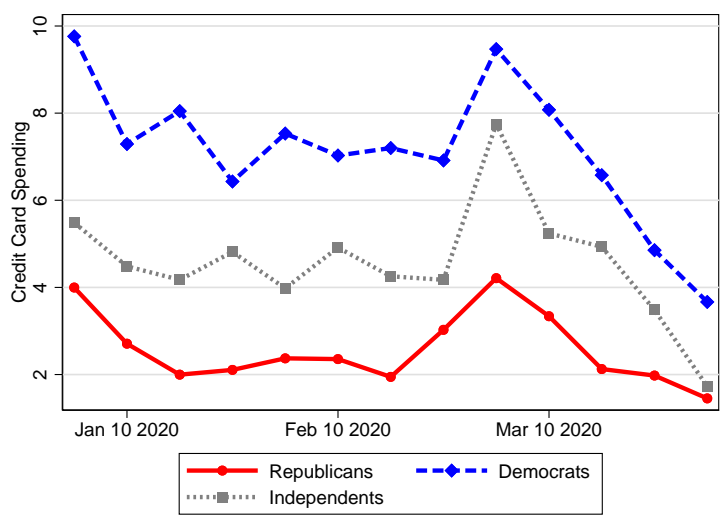


Table 1: Monthly Summary Statistics

\begin{tabular}{lccccccc}
\hline & & & & \multicolumn{5}{c}{ Percentiles } \\
& Mean & Std. Dev. & $10 \%$ & $25 \%$ & $50 \%$ & $75 \%$ & $90 \%$ \\
\hline Number of Linked Accts & 2.61 & 2.92 & 1 & 1 & 2 & 3 & 5 \\
Number of Txns & 77.06 & 64.29 & 17 & 33 & 64 & 100 & 155 \\
Payroll Income & $\$ 2,718.50$ & $\$ 3,789.80$ & $\$ 6.70$ & $\$ 410.64$ & $\$ 1,681.19$ & $\$ 3,629.03$ & $\$ 6,352.28$ \\
Groceries & $\$ 262.36$ & $\$ 351.75$ & $\$ 19.89$ & $\$ 48.01$ & $\$ 138.88$ & $\$ 351.75$ & $\$ 701.73$ \\
Restaurants & $\$ 318.97$ & $\$ 942.38$ & $\$ 16.32$ & $\$ 44.63$ & $\$ 124.66$ & $\$ 278.25$ & $\$ 652.35$ \\
Pharmacies & $\$ 53.39$ & $\$ 86.24$ & $\$ 6.47$ & $\$ 14.31$ & $\$ 30.78$ & $\$ 61.13$ & $\$ 114.26$ \\
Shopping & $\$ 165.15$ & $\$ 322.90$ & $\$ 8.55$ & $\$ 22.245$ & $\$ 69.995$ & $\$ 169.38$ & $\$ 371.31$ \\
\hline Transaction-Level Obs. & 691,542 & & & & & &
\end{tabular}

Summary statistics of the final sample of active users with complete data from March 27th. Data are monthly over users' entire smaple histories. All statistics are in USD. 


\section{Table 2: Spending by Week and Heterogeneity by State}

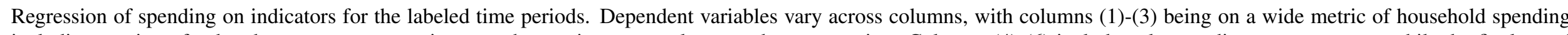

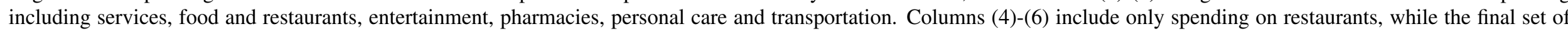

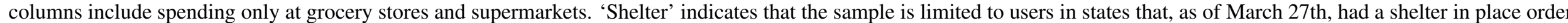
in place. 'No Shelter' restricts to users in states without such an order. Standard errors clustered at a user level. * $p<.1$, ** $p<.05, * * * p<.01$. Source: Non-Profit Fintech.

\begin{tabular}{|c|c|c|c|c|c|c|c|c|c|}
\hline VARIABLES & $\begin{array}{l}\text { (1) } \\
\text { All }\end{array}$ & $\begin{array}{c}(2) \\
\text { Shelter }\end{array}$ & $\begin{array}{c}(3) \\
\text { No Shelter }\end{array}$ & $\begin{array}{c}(4) \\
\text { All - Rest }\end{array}$ & $\begin{array}{c}(5) \\
\text { Shelter - Rest }\end{array}$ & $\begin{array}{c}(6) \\
\text { No Shelter - Rest }\end{array}$ & $\begin{array}{c}(7) \\
\text { All - Groc }\end{array}$ & $\begin{array}{c}(8) \\
\text { Shelter - Groc }\end{array}$ & $\begin{array}{c}(9) \\
\text { No Shelter - Groc }\end{array}$ \\
\hline February 26 - March 10 & $\begin{array}{c}0.516 * * * \\
(0.0273)\end{array}$ & $\begin{array}{c}0.584 * * * \\
(0.0452)\end{array}$ & $\begin{array}{c}0.491 * * * \\
(0.0765)\end{array}$ & $\begin{array}{c}0.371 * * * \\
(0.0212)\end{array}$ & $\begin{array}{c}0.335 * * * \\
(0.0407)\end{array}$ & $\begin{array}{c}0.337 * * * \\
(0.0626)\end{array}$ & $\begin{array}{c}0.273 * * * \\
(0.0208)\end{array}$ & $\begin{array}{c}0.284 * * * \\
(0.0390)\end{array}$ & $\begin{array}{c}0.269 * * * \\
(0.0633)\end{array}$ \\
\hline March 11 - March 17 & $\begin{array}{l}-0.0437 \\
(0.0318)\end{array}$ & $\begin{array}{l}0.134 * * \\
(0.0561)\end{array}$ & $\begin{array}{c}0.0701 \\
(0.0957)\end{array}$ & $\begin{array}{l}0.0463 * \\
(0.0240)\end{array}$ & $\begin{array}{l}0.0523 \\
(0.0455)\end{array}$ & $\begin{array}{l}0.159 * * \\
(0.0764)\end{array}$ & $\begin{array}{c}0.189 * * * \\
(0.0255)\end{array}$ & $\begin{array}{c}0.331 * * * \\
(0.0515)\end{array}$ & $\begin{array}{l}0.187 * * \\
(0.0827)\end{array}$ \\
\hline March 18 - March 27 & $\begin{array}{c}-0.477 * * * \\
(0.0322)\end{array}$ & $\begin{array}{c}-0.245 * * * \\
(0.0558)\end{array}$ & $\begin{array}{l}-0.159 \\
(0.0973)\end{array}$ & $\begin{array}{c}-0.313 * * * \\
(0.0235)\end{array}$ & $\begin{array}{c}-0.318 * * * \\
(0.0452)\end{array}$ & $\begin{array}{l}-0.123 \\
(0.0784)\end{array}$ & $\begin{array}{c}0.0745 * * * \\
(0.0253)\end{array}$ & $\begin{array}{c}0.232 * * * \\
(0.0519)\end{array}$ & $\begin{array}{c}0.0838 \\
(0.0860)\end{array}$ \\
\hline Observations & 61,555 & 15,886 & 6,383 & 61,555 & 15,886 & 6,383 & 61,555 & 15,886 & 6,383 \\
\hline$R^{2}$ & 0.397 & 0.431 & 0.443 & 0.397 & 0.428 & 0.443 & 0.398 & 0.415 & 0.440 \\
\hline User FE & YES & YES & YES & YES & YES & YES & YES & YES & YES \\
\hline
\end{tabular}




\section{Table 3: Spending by Week and Heterogeneity by Predicted Political Position}

Regression of spending on indicators for the labeled time periods. Dependent variables vary across columns, with columns (1)-(3) being on a wide metric of household spending including services, food and restaurants, entertainment, pharmacies, personal care and transportation. Columns (4)-(6) include only spending on restaurants, while the final set of columns include spending only at grocery stores and supermarkets. 'Dem' indicates that the sample is limited to users who are predicted to be in the top quartile of most democratic leaning based on Demographic and financial indicators. 'Rep' indicates that the sample is limited to users who are predicted to be in the top quartile of most Republican leaning based on demographic and financial indicators. Standard errors clustered at a user level. $* p<.1, * * p<.05, * * * p<.01$. Source: Non-Profit Fintech.

\begin{tabular}{|c|c|c|c|c|c|c|c|c|c|}
\hline VARIABLES & $\begin{array}{l}(1) \\
\text { All }\end{array}$ & $\begin{array}{c}(2) \\
\text { Dem }\end{array}$ & $\begin{array}{l}(3) \\
\text { Rep }\end{array}$ & $\begin{array}{c}(4) \\
\text { All - Rest }\end{array}$ & $\begin{array}{c}(5) \\
\text { Dem - Rest }\end{array}$ & $\begin{array}{c}(6) \\
\text { Rep - Rest }\end{array}$ & $\begin{array}{c}(7) \\
\text { All - Groc }\end{array}$ & $\begin{array}{c}(8) \\
\text { Dem - Groc }\end{array}$ & $\begin{array}{c}(9) \\
\text { Rep - Groc }\end{array}$ \\
\hline February 26 - March 10 & $\begin{array}{c}0.516 * * * \\
(0.0273)\end{array}$ & $\begin{array}{c}0.401 * * * \\
(0.0524)\end{array}$ & $\begin{array}{c}0.505 * * * \\
(0.0626)\end{array}$ & $\begin{array}{c}0.371 * * * \\
(0.0212)\end{array}$ & $\begin{array}{c}0.292 * * * \\
(0.0416)\end{array}$ & $\begin{array}{c}0.379 * * * \\
(0.0480)\end{array}$ & $\begin{array}{c}0.273 * * * \\
(0.0208)\end{array}$ & $\begin{array}{c}0.120 * * * \\
(0.0393)\end{array}$ & $\begin{array}{c}0.298 * * * \\
(0.0442)\end{array}$ \\
\hline March 11 - March 17 & $\begin{array}{l}-0.0437 \\
(0.0318)\end{array}$ & $\begin{array}{l}-0.0642 \\
(0.0629)\end{array}$ & $\begin{array}{l}-0.0659 \\
(0.0729)\end{array}$ & $\begin{array}{l}0.0463 * \\
(0.0240)\end{array}$ & $\begin{array}{l}-0.0153 \\
(0.0491)\end{array}$ & $\begin{array}{c}0.0638 \\
(0.0528)\end{array}$ & $\begin{array}{c}0.189 * * * \\
(0.0255)\end{array}$ & $\begin{array}{c}0.176 * * * \\
(0.0504)\end{array}$ & $\begin{array}{c}0.238 * * * \\
(0.0562)\end{array}$ \\
\hline March 18 - March 27 & $\begin{array}{c}-0.477 * * * \\
(0.0322)\end{array}$ & $\begin{array}{c}-0.572 * * * \\
(0.0661)\end{array}$ & $\begin{array}{c}-0.484 * * * \\
(0.0720)\end{array}$ & $\begin{array}{c}-0.313 * * * \\
(0.0235)\end{array}$ & $\begin{array}{c}-0.460 * * * \\
(0.0487)\end{array}$ & $\begin{array}{c}-0.364 * * * \\
(0.0496)\end{array}$ & $\begin{array}{c}0.0745 * * * \\
(0.0253)\end{array}$ & $\begin{array}{c}0.0755 \\
(0.0504)\end{array}$ & $\begin{array}{c}0.0595 \\
(0.0544)\end{array}$ \\
\hline Observations & 61,555 & 15,080 & 12,922 & 61,555 & 15,080 & 12,922 & 61,555 & 15,080 & 12,922 \\
\hline$R^{2}$ & 0.397 & 0.388 & 0.386 & 0.397 & 0.392 & 0.381 & 0.398 & 0.397 & 0.393 \\
\hline User FE & YES & YES & YES & YES & YES & YES & YES & YES & YES \\
\hline
\end{tabular}




\section{Table 4: Spending Response Heterogeneity by Demographic and Financial Indicators}

Regression of spending on indicators for the labeled time periods. Dependent variables vary based on Panel. Panel A includes a wide metric of household spending including services, food and restaurants, entertainment, pharmacies, personal care and transportation. Panel B includes only spending on restaurants, while Panel C Includes spending only at grocery stores and supermarkets. In each panel, we interact indicators for the listed periods with indicators for demographic and financial characteristics, listed above the columns. Column (1) interacts with whether the user is under 30 years old. Column (2) interacts with an indicator for whether the user has children. Column (3) interacts with an indicator for whether the user is male. Column (4) interacts with an indicator for whether the user earns above $\$ 40,000$ per year. Standard errors clustered at a user level. $* p<.1, * * p<.05$, *** $p<.01$. Source: Non-Profit Fintech.

\begin{tabular}{|c|c|c|c|c|}
\hline & (Young) & (Children) & (Male) & (High Income) \\
\hline & \multicolumn{4}{|c|}{ Panel A. All Spending } \\
\hline February 26 - March 10 & $\begin{array}{c}0.550 * * * \\
(0.0521)\end{array}$ & $\begin{array}{c}0.529 * * * \\
(0.0365)\end{array}$ & $\begin{array}{c}0.567 * * * \\
(0.0355)\end{array}$ & $\begin{array}{c}0.550 * * * \\
(0.0384)\end{array}$ \\
\hline March 18 - March 27 & $\begin{array}{c}-0.481 * * * \\
(0.0617)\end{array}$ & $\begin{array}{c}-0.271 * * * \\
(0.0460)\end{array}$ & $\begin{array}{c}-0.379 * * * \\
(0.0421)\end{array}$ & $\begin{array}{c}-0.355 * * * \\
(0.0451)\end{array}$ \\
\hline February 26 - March 10*Group & $\begin{array}{c}0.0364 \\
(0.0675)\end{array}$ & $\begin{array}{c}0.111 \\
(0.0908)\end{array}$ & $\begin{array}{l}-0.142 * \\
(0.0759)\end{array}$ & $\begin{array}{c}0.0144 \\
(0.0790)\end{array}$ \\
\hline March 18 - March 27*Group & $\begin{array}{c}0.234 * * * \\
(0.0807)\end{array}$ & $\begin{array}{c}-0.329 * * * \\
(0.100)\end{array}$ & $\begin{array}{l}-0.0115 \\
(0.0912)\end{array}$ & $\begin{array}{l}0.0243 \\
(0.102)\end{array}$ \\
\hline $\begin{array}{l}\text { Observations } \\
R^{2} \\
\text { User FE }\end{array}$ & $\begin{array}{c}32,838 \\
0.414 \\
\text { YES }\end{array}$ & $\begin{array}{c}30,446 \\
0.419 \\
\text { YES }\end{array}$ & $\begin{array}{c}38,701 \\
0.412 \\
\text { YES }\end{array}$ & $\begin{array}{c}31,564 \\
0.416 \\
\text { YES }\end{array}$ \\
\hline User FE & \multicolumn{4}{|c|}{ Panel B. Restaurant Spending } \\
\hline February 26 - March 10 & $\begin{array}{c}0.307 * * * \\
(0.0405)\end{array}$ & $\begin{array}{c}0.322 * * * \\
(0.0321)\end{array}$ & $\begin{array}{c}0.407 * * * \\
(0.0295)\end{array}$ & $\begin{array}{c}0.358 * * * \\
(0.0321)\end{array}$ \\
\hline March 18 - March 27 & $\begin{array}{c}-0.317 * * * \\
(0.0448)\end{array}$ & $\begin{array}{c}-0.269 * * * \\
(0.0371)\end{array}$ & $\begin{array}{c}-0.292 * * * \\
(0.0328)\end{array}$ & $\begin{array}{c}-0.262 * * * \\
(0.0358)\end{array}$ \\
\hline February 26 - March 10*Group & $\begin{array}{c}0.0812 \\
(0.0554)\end{array}$ & $\begin{array}{c}0.0883 \\
(0.0708)\end{array}$ & $\begin{array}{c}-0.200 * * * \\
(0.0611)\end{array}$ & $\begin{array}{l}-0.0370 \\
(0.0666)\end{array}$ \\
\hline March 18 - March 27*Group & $\begin{array}{c}0.0703 \\
(0.0619)\end{array}$ & $\begin{array}{l}-0.0266 \\
(0.0750)\end{array}$ & $\begin{array}{c}0.0239 \\
(0.0660)\end{array}$ & $\begin{array}{l}-0.0452 \\
(0.0765)\end{array}$ \\
\hline Observations & 32,838 & 30,446 & 38,701 & 31,564 \\
\hline$R^{2}$ & 0.412 & 0.418 & 0.41 & 0.416 \\
\hline \multirow[t]{2}{*}{ User FE } & YES & YES & YES & YES \\
\hline & \multicolumn{4}{|c|}{ Panel C. Grocery Spending } \\
\hline February 26 - March 10 & $\begin{array}{c}0.278 * * * \\
(0.0419)\end{array}$ & $\begin{array}{c}0.245^{* * *} * \\
(0.0313)\end{array}$ & $\begin{array}{c}0.318 * * * \\
(0.0298)\end{array}$ & $\begin{array}{c}0.304 * * * \\
(0.0321)\end{array}$ \\
\hline March 18 - March 27 & $\begin{array}{c}0.0169 \\
(0.0532)\end{array}$ & $\begin{array}{c}0.140 * * * \\
(0.0421)\end{array}$ & $\begin{array}{c}0.110 * * * \\
(0.0371)\end{array}$ & $\begin{array}{c}0.129 * * * \\
(0.0407)\end{array}$ \\
\hline February 26 - March 10*Group & $\begin{array}{c}0.0276 \\
(0.0555)\end{array}$ & $\begin{array}{c}0.205 * * * \\
(0.0721)\end{array}$ & $\begin{array}{c}-0.150 * * * \\
(0.0569)\end{array}$ & $\begin{array}{l}-0.0491 \\
(0.0659)\end{array}$ \\
\hline March 18 - March 27*Group & $\begin{array}{c}0.197 * * * \\
(0.0706)\end{array}$ & $\begin{array}{l}-0.0273 \\
(0.0828)\end{array}$ & $\begin{array}{l}-0.0412 \\
(0.0705)\end{array}$ & $\begin{array}{c}0.0153 \\
(0.0853)\end{array}$ \\
\hline Observations & 32,838 & 30,446 & 38,701 & 31,564 \\
\hline$R^{2}$ & 0.40834 & 0.411 & 0.41 & 0.407 \\
\hline User FE & YES & YES & YES & YES \\
\hline
\end{tabular}

